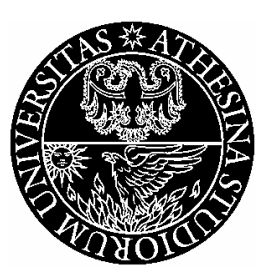

UNIVERSITA' DEGLI STUDI DI TRENTO - DIPARTIMENTO DI ECONOMIA

\title{
THE ECONOMIC CONSEQUENCES OF MR. G.W. BUSH'S FOREIGN POLICY. CAN THE US AFFORD IT?
}

ROBERTO TAMBORINI 
The Discussion Paper series provides a means for circulating preliminary research results by staff of or visitors to the Department. Its purpose is to stimulate discussion prior to the publication of papers.

Requests for copies of Discussion Papers and address changes should be sent to:

Dott. Edoardo Gaffeo

Dipartimento di Economia

Università degli Studi

Via Inama 5

38100 TRENTO - ITALY 


\section{The economic consequences of Mr. G. W. Bush's foreign policy. Can the US afford it?}

Roberto Tamborini ${ }^{*}$

\footnotetext{
* University of Trento, Department of Economics, Via Inama 5, 38100 Trento, Italy,

Tel. 0461-882228, Fax. 0461-882222

e-mail: roberto.tamborini@economia.unitn.it
} 


\begin{abstract}
Current analyses of the so-called "neoconservative" turn in US foreign policy tend to neglect its economic requirements and consequences. This is probably due to their long-run and uncertain nature, and yet one expects the foreign policy choices of a global power to be made with a clear understanding of their probable long-run economic costs and sustainability. The economic implications of unilateralism for the US may be complex and may stretch far beyond the accounting of the Afghan and Iraq campaign. The phenomenon that we should examine, if unilateralism is going to be a lasting choice, is a return to huge external borrowing requirement since Reagan's "Star Wars" programme. The paper, intended for a non-economist readership, seeks to ascertain whether the ensuing scenario will be stable and sustainable from two interrelated perspectives. The first one draws together the various possible consequences suggested by standard international economic analysis. The second one is a historical-comparative analysis of the position of the US in the present global economic system vis-à-vis the previous experiences of Great Britain before World War I, and the US after Wordl War II.
\end{abstract}




\section{THE ECONOMIC CONSEQUENCES OF MR. G. W. BUSH'S FOREIGN POLICY. CAN THE US AFFORD IT?}

\section{Introduction}

Substantial agreement exists that the Bush Administration has announced, and is undertaking, a major shift in the international policy of the United States aimed at the unilateral exercise of global power according to an extensive definition of "national interest" and "national security", inclusive of the establishment of the "world democratic order" by means of armed force. This new strategy is considered to be inspired by the so-called "neoconservative" doctrine, which stresses the right and power of the US to lead the politics of the free world, with no permanent commitments towards, and constraints by, multilateral organizations. What has an economist to say about this new international policy stance of the US?

It is well known to economists, as well as to political scientists of almost all persuasions, that economic and political choices are intimately related. Very generally speaking, the influence of the economy on the political sphere can be traced back to two main factors: motivations -whether "need" or "greed" - that induce political choices, and constraints that set limits on political choices (Gilpin (2003)). While much debate focuses on the former factor - e.g. control over oil production and other vested interests of major Bush's supporters - in this paper attention will be drawn to the role of the economy as a constraint on political choices.

According to a well-known definition, economics is the science of allocation of scarce resources to alternative ends in society. This definition concerns more a method than a specific matter of analysis, and a method can, in principle at least, be applied to different matters. Indeed, there are many social situations - though not all of them - 
where the scarcity of resources with respect to competing ends raises difficult choice problems. In most such cases, the real value added of economics is negative and consists in pointing out the expected implications of different courses of action, and hence the limits to feasible choices. On the other hand, the extent of economic resources and the extent of power are often interrelated, and each may be instrumental to expanding the other. Thus, a politician may use his/her power to relax economic constraints on his/her set of feasible choices; and if political power is considerable, the politician may be tempted to believe that economic constraints are negligible. History, as we shall see, suggests that this belief is groundless even for international "superpowers". There is, however, a specific dimension of economic constraints that may justify the attitude of politicians to ignore them: namely that these constraints typically unfold over time - technically speaking they are "intertemporal" constraints. As a consequence, they may be difficult to predict and appraise, and, what is more intriguing, the expected horizon of the politician's political life may be shorter than the time taken for the constraints to materialize. Thus, the unsustainability of seemingly grand and successful political designs may harm society a few generations later, and possibly fall on the shoulders of a different political party.

The so-called "New Political Economics" (see e.g. Persson and Tabellini (1990)), with its distinctive sceptical attitude towards the economic rationality of democracy, views the (self-interested) myopia of policy makers as a major flaw in democratic systems based on predictable majority reversals. Advocates of this view suggest two remedies. The first is "tying governments' hands" by means of constitutional rules embodying the interests of yet-to-be-born constituencies. The second is exposing governments to the "constituency of markets" too (by e.g. allowing free capital movements) on the grounds that "markets" are particularly skilful in intertemporal calculation and are able to anticipate the effects of right constraints in real time.

All the foregoing considerations contribute to make the economic analysis of the new US international political stance a serious and challenging matter. The US Administration does enjoy political power in the international arena to an unprecedented extent. This power indeed relaxes some economic constraints that other "ordinary" 
countries face. On the other hand, the American democratic system is such that majority reversals are frequent and predictable, whereas constitutional protections against governments' short-termism are not particularly strong (they are in fact much weaker than those contained in the EU Maastricht Treaty and Stability and Growth Pact). Nor do super-national regulations of such a nature exist. The exposure of US governments to markets is high, but the faith in markets as far-sighted real-time voters is no longer as great as it used to be. Hence, if one considers whether the new US international policy stance has been tested against its long-run economic feasibility, not only does one realize that the Administration seems to have paid remarkably scant attention to this dimension in the public debate, but one is also led to suspect that little pressure is felt to focus on it ${ }^{1}$.

The non-economist reader will find in section 2 a quick guide to the international economic constraints that a country operating in free and integrated world markets faces. The simple indicators presented in section 2 focus on the long-run sustainability of a country's international position. Section 3 will enlarge the picture, providing a few basic insights into the domestic as well as international economic implications of international political choices. The key message is that the feasibility of these choices can be ranked according to their consistency with the long-run sustainability of the ensuing economic implications. These basic principles will be seen in action in section 4, which examines two major historical antecedents when a single country ruled the political-economic world system of capitalist countries, Great Britain from 1870 to 1915 and the US from 1945 to 1973 . The purpose of these historical comparisons is to highlight patterns of world politicaleconomic governance which should not and cannot be mechanically applied to the present situation of the US, but can offer better guidance in gauging the long-run feasibility of the neoconservative strategy than mere (unreliable) projections of the costs of wars. This assessment exercise will be presented in section 5, drawing attention to the present world debtor position and international financial phase of the US

1 The resignation of Paul O'Neill from the Treasury, which seems motivated by most of the concerns raised in this paper, has apparently had no substantial impact on the political-economic line of the Administration. 
economy. This position is at odds with succesful antecedents and appears highly problematic for the neoconservative programme for two reasons: one is that considerations of international financial stability leave too little room for the large fiscal deficits and external borrowing required by the programme; the other is that high external debt is hardly consistent with the "free-hand", unconditioned exercise of political will invoked by the neconservatives. Section 6 will present a few concluding remarks.

\section{International economic constraints}

In this section I will point out a few concepts that define the basic international economic constraints faced by countries operating in integrated world markets.

Traditionally, the key issue in a long-run perspective is under what conditions each country brings its worldwide transactions in goods and assets into balance, which is known as the "balance-of-payments (BOP) constraint". Apparently, this is nothing but the worldwide application of the principle of equal exchange which requires any individual (country) to meet payments with receipts. Note, however, that it is the existence of nation-states with monetary sovereignty and different legal tenders - two facts hard to accommodate in the pure theory of value and exchange - that introduces the specific dimension of international economic constraints which we will consider. Indeed, it is monetary sovereigns who directly perceive the BOP constraint, whereas private agents may only face it to the extent that monetary authorities are willing or able to enforce it. ${ }^{2}$ Let me now recall how this responsibility is exerted.

Different legal tenders force private agents to trade them in order to be able to pay for cross-border transactions. The development of international trade requires the parallel development of markets for

2 At the individual level, where goods are bought and sold, and the unit of account in which they are quoted, is, or should be, immaterial. If a household sells labour "at home" but buys goods "abroad" it may well keep its private budget in equilibrium, whereas its country records a BOP disequilibrium. 
currencies granting convertibility and efficient exchange-rates quotations (i.e the prices at which currencies are traded against each other).

Table 1. International accounting

\begin{tabular}{|c|c|}
\hline Receipts & Payments \\
\hline \multicolumn{2}{|c|}{ Trade (X) } \\
\hline Exports of goods and services & Imports of goods and services \\
\hline \multicolumn{2}{|c|}{ Incomes and transfers (YF) } \\
\hline $\begin{array}{l}\text { Labour and capital incomes from } \\
\text { non-residents }\end{array}$ & $\begin{array}{r}\text { Labour and capital incomes to non- } \\
\text { residents }\end{array}$ \\
\hline $\begin{array}{l}\text { Unilateral transfers and non-market } \\
\text { obligations towards non-residents }\end{array}$ & $\begin{array}{l}\text { Unilateral transfers and non-market } \\
\text { obligations from non-residents }\end{array}$ \\
\hline \multicolumn{2}{|c|}{ Capitals (K) } \\
\hline $\begin{array}{l}\text { Sales of assets to non-residents } \\
\text { ("capital inflows") }\end{array}$ & $\begin{array}{l}\text { Purchases of assets from non- } \\
\text { residents ("capital ouflows") }\end{array}$ \\
\hline Total supply of foreign currency & Total demand of foreign currency \\
\hline
\end{tabular}

The demand for foreign currency in one country is determined by the sum of external payments, while the supply of the same foreign currency is determined by the sum of external receipts ${ }^{3}$. Usually, external transactions are recorded under three different categories, as in the table above. The important differences between them will become clear in due course. The net balance between supply of and demand for foreign currency corresponds to the so-called "fundamental" BOP, which is the result of all autonomous international transactions by the private and public sectors other than monetary authorities. In what follows, this will be our measure of BOP.

3 This principle of course applies to the currency of each of a given country's trade partners. For simplicity, I shall consider all external partners to be a single entity with a single currency. 
In the short run, the demand for and supply of foreign currency may happen to be different (or equivalently, BOP $\neq 0$ ). Two different mechanisms may then be triggered. The first is that the monetary authority absorbs excess demand or supply at the current exchange rate by reducing or increasing its own stock of foreign currency reserves or other compensatory items under its control ("fixed exchange-rate regime"). In algebraic form, taking the net balance of each international account,

$$
X_{t}+Y F_{t}+K_{t}=\Delta O R_{t}
$$

where $\Delta O R_{t}>0$ is an increase, and $\Delta O R_{t}<0$ a decrease, in official reserves.

Alternatively, the monetary authority may let the exchange rate float ("floating exchange-rate regime"), in which case excess demand for foreign currency brings about domestic currency depreciation (the price of foreign currency rises), while excess supply brings about appreciation (the price of foreign currency falls). Exchage-rate adjustments are generally allowed for on the expectation that they will help rebalance international accounts spontaneously. Again using relationship (1),

$$
\begin{aligned}
& X_{t}+Y F_{t}+K_{t}>0, \Delta O R_{t}=0, \Rightarrow \text { appreciation } \\
& X_{t}+Y F_{t}+K_{t}<0, \Delta O R_{t}=0, \Rightarrow \text { depreciation }
\end{aligned}
$$

Yet reserves cannot be increased or decreased, nor can the domestic currency depreciate or appreciate, indefinitely. Hence, whatever the choice of exchange-rate regime, monetary sovereignty in an integrated world economy implies that external payments and receipts are sooner or later brought into balance. Consequently, the usual expression for the BOP constraint is

$$
X_{t}+Y F_{t}+K_{t}=0
$$

At first sight, this constraint can be fulfilled by various combinations of the various accounts. However, in order to understand the evolution of international payments and the time profile of their constraint, it is necessary to examine the three different categories of international transactions more closely. As can be seen in Table 1, they have quite different economic nature in relation to time. 
The trade account concerns transactions in goods and services. These may be regarded as having negligible intertemporal repercussions, in the sense that they are performed within their accounting period and give rise to no commitments beyond it. When General Motors sell cars to Europe, these are generally paid for in cash or with negligible delay ${ }^{4}$, and the relationship between the US and the EU is concluded. At the opposite end of the spectrum lie transactions on capital account, which by their very nature establish commitments extending into the distant future. If General Motors sell bonds to European savers, the concomitant capital inflow is still recorded as a current US receipt, but the US are also indebted with the EU to the amount of principal and interests. This counterpart of today's financial transaction will show up in tomorrow's payments on incomes account when GM services its debt to EU bond-holders. Of course, the reverse holds for the EU, which records capital outflows today but will receive more foreign incomes tomorrow. Thus, the incomes account is largely predetermined by previous foreign assets and liabilities and arises from international market obligations (except for labour incomes, which depend on migration flows and remittances). This account is usually integrated with unilateral transfers and non-market obligations: that is, private and public commitments towards and from non-residents, such as international grants and aid, participations in international institutions, military expenditure abroad. Since trade, incomes and transfer payments result from transactions that do not change assets or liabilities, they can also be aggregated into a single account, the current account, as opposed to the capital account, which records transactions which change assets or liabilities. Therefore, the same aggregate balance of receipts and payments, and even a zero total sum of the BOP, may hide marked differences as regards the future evolution of the accounts. There are two principal patterns.

- The debtor country

$$
X_{t}<0, Y F_{t}<0, K_{t}>0
$$

${ }^{4}$ Commercial credit may be extended, but its time-horizon can be considered relatively short with respect to the economic phenomena under examination here. 
In this pattern, balance-of-payments equilibrium is the result of trade and incomes deficits vis-à-vis capital inflows. The country acts as a debtor since capital inflows imply sales of assets and an increase in liabilities with non-residents, whereas the trade deficit indicates that the country is buying more than it is selling abroad. Because the debtor position stretches over time, also the incomes account tends to turn negative, owing to the debt service payments.

\section{- The creditor country}

$$
X_{t}>0, Y F_{t}>0, K_{t}<0
$$

This pattern is the reverse of the previous one, in that BOP equilibrium is now the result of trade and incomes surpluses with capital outflows. The three accounts indicate that the country as a whole is lending abroad, hoarding assets towards non-residents, while it is selling more goods than it is buying abroad, with positive incomes gained from foreign assets.

Of course, in spite of the rhetoric of economics and politics, countries are not anthropomorphic entities. Their stance on the international economic stage is the result of many independent choices made by private and public agents. The connection between international accounts and national accounts highlights the economic forces behind a country taking a debtor or creditor position. Given (after tax) gross domestic product $Y_{t}$, private domestic consumption $C_{t}$ private domestic investment $I_{t}$, and the government deficit $D_{t}$ (total public expenditure - total tax revenue), the following identity holds,

$$
Y_{t}-\left(C_{t}+I_{t}+D_{t}\right)=X_{t}
$$

where the sum $\left(C_{t}+I_{t}+D_{t}\right)$ yields the so-called domestic real absorption. Therefore, a trade surplus (deficit) arises as the economy absorbs less (more) goods and services than it produces, the difference being made up by net exports to (imports from) the rest of the world.

The financial counterpart of the previous relationship is crucial. Note, first, that non-zero private investment and public deficit imply that private firms and the government borrow from households. Since $Y_{t}+Y F_{t}$ yields national income, and the difference $Y_{t}+Y F_{t}-C_{t}$ yields private saving $S_{t}$, under BOP equilibrium it follows from (5) and (2) that 


$$
S_{t}-\left(I_{t}+D_{t}\right)=X_{t}+Y F_{t}=-K_{t}
$$

where the sum $\left(I_{t}+D_{t}\right)$ corresponds to the domestic financial absorption.

Let us begin with a debtor country and suppose that initially $Y F_{t}=0$. As we know from expression (3), this country will display a negative trade account, $X_{t}<0$, and a positive capital account, $K_{t}>0$. Expression (6) tells us that in this country private saving, which represents the domestic supply of financial resources, falls short of the domestic financial absorption ${ }^{5}$, resulting in a net external borrowing requirement covered by capital inflows. As is often said, a debtor country - like any debtor indeed - "lives above its own means" by absorbing real and financial resources from the rest of the world. By contrast, a creditor country "lives below its own means" by transferring real and financial resources to the rest of the world, in the sense that private saving exceeds the domestic financial absorption, excess saving is channeled abroad through capital outflows, $K_{t}<0$, while the concomitant excess of domestic production is sold abroad and is reflected in a trade surplus, $X_{t}>0$.

To conclude this overview of international accounts and constraints, it should be stressed that, on closer inspection, even the previous patterns of BOP equilibrium may well persist for a long time, but they cannot be sustained indefinitely. A critical variable is represented by foreign incomes. The reason is that as long as the capital account is unbalanced, the country as a whole goes on accruing assets or liabilities towards non-residents. Over time, two main consequences arise. The first is that, even though $K_{t}$ and $X_{t}$ were to remain constant, $Y F_{t}$ would tend to grow larger and larger, whether positive or negative, thus bringing overall payments out of balance ${ }^{6}$. The second consequence is due to the elementary financial principle whereby no country can rely

\footnotetext{
5 If the government budget is positive, it adds to private saving.

6 Consider any country facing a world interest rate $r$. Its yearly incomes account is $r$ times its oustanding liabilities/assets. The latter are the sum of previous capital inflows/outflows, so that the year incomes account is

$$
Y F_{t}=r \Sigma K_{t}
$$

which continues to increase as long as $K_{t} \neq 0$.
} 
on indefinite net capital inflows or outflows because the acceptance of country-specific assets and liabilities in the world financial markets is limited. These markets tend to obey to portfolio diversification rules focused on proportions of country-specific securities related to their return-risk profile ${ }^{7}$.

Take the case of a debtor country. This country's securities should grow year after year in world portfolios, with a rising risk profile. To rebalance portfolios, purchases of these securities are reduced so that $K_{t}$ falls as $Y F_{t}$ payments grow mechanically. To sustain $K_{t}$, financial markets demand a higher interest rate rate or a currency appreciation (see fn. 7); but the former measure accelerates the growth of $Y F_{t}$ payments whereas the latter widens $X_{t}$. Therefore, a "mature" debtor country tends spontaneously to display a growing negative current account and/or decreasing capital inflows, which is not compatible with the BOP constraint. Hence either the debtor develops a positive trade account over time or its position is unsustainable in the long-run, i.e.

$$
X_{t}>0, Y F_{t}<0, K_{t}>0
$$

A creditor country has of course a specular evolution, with positive $Y F_{t}$ payments progressively adding to trade surpluses, so that a growing positive current account is typical of a so-called "mature" creditor, or international rentier. However, since to any creditor country there corresponds a debtor country, the limits to the sustainability of debtor positions also set the limits to the sustainability of creditor positions. Hence, if a mature debtor must develop a trade surplus,

7 It is worth recalling the simple formula which stat $_{\mathrm{es}}$ that the rate of return to a country-specific security $r_{i}$ should be

$$
r_{i}=r-\varepsilon_{i}+p_{i}
$$

where $r$ is the world risk-free rate, $\varepsilon_{i}$ is the expected rate of currency appreciation and $p_{i}$ is its own country-risk premium. Suppose $r=5 \%, p_{i}=1 \%$ and no expected change in the exchange rate, $\varepsilon_{i}=0$. Then, $r_{i}=6 \%$. Now suppose that $p_{i}=2 \%$. Consequently, either the country-specific return rate increases up to $r_{j}=7 \%$ or foreign investors should expect a currency appreciation $\varepsilon_{i}=1 \%$ (or a combination of the two). The currency appreciation is necessary because it increases the take-home value of interest payments. 
sustainability of world payments implies that a mature creditor must accommodate a trade deficit, i.e.

$$
X_{t}<0, Y F_{t}>0, K_{t}<0
$$

It will be observed that, with reference to the patterns of payments (3) and (4), "maturity" implies that the sign of the trade account in the debtor and creditor country is reversed. There are only two ways in which this can be obtained in relation to the exchange-rate regime. Under fixed exchange rates, the debtor country should be able to raise GDP above domestic real absorption (ore equivalently private saving above domestic financial absorption) with the creditor country moving in the opposite direction. If the exchange rate is free to float, the foregoing adjustment can be accomplished by depreciating the debtor country's currency vis-à-vis the creditor country's. The timing and precision of the co-evolution of debtor and creditor positions is the extremely delicate mechanism underlying world economic and financial stability. An important conceptual consequence is that if "equilibrium" is to be understood in its strict meaning of indefinitely sustainable position, a third pattern of international payments should be introduced.

\section{- Full equilibrium}

$$
X_{t}=0, Y F_{t}=0, K_{t}=0
$$

This is an ideal benchmark in which all accounts are balanced. The economic meaning and relevance of this pattern is conceptual. Though full equilibrium is hardly observable in practice, it acts as a "gravity centre" around which actual country positions revolve, and, more importantly, it represents the benchmark against which they can be measured and assessed. The unsustainability of creditor-debtor positions can materialize more or less smoothly depending on the growth speed of foreign debt, the country-risk assessment, the level of world interest rates and exchange-rate expectations (see e.g. the formula in fn. 7). Currency crises and BOP crises are typically triggered by sudden reversals of capital inflows as foreign investors abruptly "discover" that the above ingredients are no longer mutually consistent. 
The role of expectations is critical, as hey may, rightly or wrongly, induce a crisis well before actual figures reveal or justify it.

\section{Some economics of international politics}

Let us now move closer to the central topic of this paper, namely the interaction between the "hard laws of economics" outlined above and a country's choice of its international political stance. The latter will be considered in a highly simplified and stylized way as a country's ability to control external political resources. This ability may acquire a variety of nuances, such as "influence", "leadership", "hegemony", "imperialism", etc. Differences among these forms of the exercise of international power, albeit important, fall outside the scope of this paper. They will instead be examined along a common dimension, that is to say the implications of a given international political stance in terms of a country's domestic and international economic pattern.

It is well known that a country's international political status does not come as a 'free lunch' or by pure political will. It is the long-run outcome of a complex mixture of historical pre-conditions and political and economic choices. Both private and public economic choices concur to determining a country's feasible international political stance. For instance, the geographical extent of a country's political influence is often dictated by the extent of its "national interests", which in turn depends on the expansion of international trade and finance developed by the private sector. The endeavour to protect national interests is generally accompanied and enforced by the development of the "foreign affairs apparatus" (diplomacy and army), and this in turn implies a consistent path of public expenditure both domestically and abroad. Note that the problem is wider and deeper than the so-called "war finance", though this may be predominant in some circumstances. Likewise, the so-called "costs of the empire" in terms of direct public expenditure abroad (see the item "transfers and non-market obligations" in Table 1) may be relevant, but it should not be our exclusive concern. As seen above, it is the interaction between the longrun saving and investment choices of the private sector, on the one hand, and the budgetary choices of governments, on the other, that eventually determines the country's international economic pattern. 
Thus, an international political stance is feasible as long as it is associated with a sustainable international economic pattern of the country.

A paradigmatic example of modern analysis of the economic implications of international political status is provided by Kindleberger (1976, 1981), who examined the role of the US in the post-World-War-II international order and proposed that it should be defined as one of international leadership. Kindleberger pointed out that sheer will, political power, or even command over material and strategic resources are not enough in themselves for a country to become an international leader. The difference lies in the presence of international responsibility among the government's objectives. In other words, an international leader must be aware of the external consequences of its actions, must be able to include its partners' benefit among its own targets, and to this effect it must be ready to restrict its set of feasible choices according to its international commitments. This general principle is shared by a variety of other analyses of international power, not only concerning leadership but also hegemony (Kehoane (1980)) or even imperialism (Arrighi (1978)).

The case that Kindleberger took from the economist's tool box is the so-called provision of public goods. Defence is the textbook example of a public good, and it was indeed the key issue in international politics during the 1960s and 1970s. Defence is a public good because everyone benefits from it, but no one in isolation has enough resources or incentives to pay for it, once account is taken of the fact that if any single individual or coalition of individuals pays for defence then it is not possible to exclude from the benefits those who have not contributed. Hence no one will ever pay for defence on a voluntary basis. When the coalition of individuals that we call "the state" exists, the solution to the provision of public goods is compulsory contribution enforced by law and legal sanction - i.e. taxation. In the post-war Western international coalition of states, in the absence of a super-state authority, the solution was a type of informal semi-voluntary exchange. The leader of the coalition would bear the (bulk of the) costs of defence and reap the benefits of leadership. The members of the coalition would enjoy defence with limited loss of sovereignty and minimal waste of resources. Total security supply would be maximized, total defence 
expenditure would be minimized. If, drawing on Arrighi's taxonomy (1978), we move from the "informal" to "formal" exercise of international power, such as modern colonialism or imperialism, we find that participation in the exchange is of course no longer voluntary, and the loss of sovereignty and economic resources by subject countries is substantial. Nonetheless, the mother country still faces a number of costly international commitments towards subject countries as well as other countries.

The fact that the exercise of international power imposes a constraint on the leader's or emperor's domestic choices is made clear by another economic textbook story. Insofar as resources are limited, any government is confronted by the alternative between producing butter or guns. If more guns are produced to meet international commitments, less butter is left for home taxpayers. Inwardness and pure domestic self-interest are not compatible with the pursuit of high international status. This is a recurrent theme in the culture of international powers, from Rome to Great Britain to the United States. Both the British and the US past experiences teach that international power may postpone the domestic butter-or-guns dilemma but cannot eliminate it in the long-run. As explained in the previous section, one way in which the excess of public expenditure (say guns and butter) over net private saving is remedied is by borrowing from abroad. This way out is only possible if there are other countries and/or private agents in the world which are willing to lend. Credit-worthiness may be largely supported by international status but it cannot be so indefinitely. Whatever the extent and intensity of the international status of a country, the law of power and strength should give way to the "law of the market", which eventually imposes, sometimes painfully, a reconciliation between domestic economic choices and international political aspirations. (Gilpin (2003))8. The USSR, which strived not to be subject to the law of the market, ran up against the butter-guns trade-off rather quickly.

\section{Historical antecedents}

8 Ardant (1976) and Kindleberger (1984) provide vivid historical analyses showing this principle in action during the great European wars in the fifteenth to seventeenth centuries. 
The best way to grasp the implications of the general ideas put forward in the previous sections, and to introduce examination of the present situation of the US, is to provide brief sketches of two major historical cases of the economic success and crisis of international powers: Great Britain and the Empire in the second half of the nineteenth century, the US and its world leadership in the thirty years after World War II.

\subsection{Great Britain and the Empire, 1850-1914}

In the second half of the nineteenth century, Great Britain reached the apogee of her international economic and political power. This status was to a large extent manifest in the formal and direct exercise of power over subject countries in an imperial system mostly located in the Eastern and Southern hemispheres. No less important, however, was a complex nexus of international relations also involving independent countries in the Western hemisphere. The relationship between Britain's international economic and political stance is complex and provides an invaluable lesson on the economic sustainability of international political ambitions.

Great Britain entered her golden age as a leader in industry and trade, and as a world creditor country. In 1850 Britain held 25\% - i.e. the largest share - of both world manufactured products and world trade. From 1860 to 1890 London invested some 1.3 billion pounds abroad, at a pace of 65 million a year. Between 1890 and 1914 foreign investment surged to 2.7 billion pounds, averaging 108 million each year. On the eve of World War I the British capital invested abroad amounted to about 4 billion pounds accounting for $45 \%$ of total foreign investment by major industrialized countries (Hobsbawm (1968), ch.7). Hobsbawm, like many others, argues that British international economic relations mostly developed independently of political power. If one looks at the geographical composition of foreign investment one indeed finds that up to 1870 territories under direct British control accounted for less than $35 \%$ of total investment, the remainder being concentrated in Southern Europe, North America and Latin America. Yet data on new issuances in London in the subsequent three decades 
show that the concentration of foreign investment in controlled territories increased sharply, so that by the end of the century its geographical composition between dependent and independent countries was almost balanced (De Cecco (1975), p. 53, Hobsbawm (1968), table 36).

A key institutional aspect of Britain's relations with other independent countries was participation in the international monetary system known as "gold standard". Formally, this was a system with gold as exclusive means of international payment, and currencies quoted in terms of gold, which resulted in mutually fixed exchange rates. The traditional wisdom in the international community was that gold reserves were critical, and that the BOP constraint was binding since payments imbalances would give rise to gold transfers from deficit to surplus countries. Summary data of Britain's international payments are given in Table A1 in the Appendix ${ }^{9}$. From this viewpoint, the most striking feature was that Britain lost her supremacy in industry and trade. From 1850 to 1900 the British economy halved its share of world manufactured goods and never regained a surplus in the merchandise trade balance. The trade account was barely corrected by large remittances from transport services. How could a heavily capital exporting country with a worsening trade account survive the BOP constraint? The key to success was foreign incomes, as can be appreciated from

9 Owing to a lack of reliable data, the capital account only displays long-run capital movements. 
Figure 1. In an "average year", interests and dividends were by themselves more than enough to compensate for the deficit in goods and services and for foreign investments ${ }^{10}$. The current account was consistently positive and tendentially increasing (see table A1 in Appendix). Hence, Britain was able to manage her BOP and maintain her commitment to gold as long as her economy was broadly consistent with the mature creditor, or international rentier, pattern discussed above. In parallel, Britain's mature debtor countries were able to service their debts thanks to their sales of goods to the mother country.

Since the British BOP was tendentially positive, a stabilizing role was also increasingly played by short-term capital movements in paper sterlings from and to London. Overall, world gold reserves, and the British ones in particular, were unable to keep pace with the growth rate of world trade. As a number of studies have pointed out, the gold standard was in fact turned into a sterling standard, with the British currency being largely used in international transactions and reserves instead of gold (Triffin (1969), Williams (1968), De Cecco (1975)). And as a rentier, Britain offered absolute security to those who came "even from the Moon" (McMillan Report) to deposit in London. Thus, a few basis points of increase in interest rates sufficed to attract enough short-term capitals to rebalance overall payments.

10 The available data do not allow identification of unilateral transfers in the incomes account. Government transfers were certainly substantial in relation to the imperial apparatus, although administrative costs were partly recovered from local administrations in the Dominions. The aggregate extent of military expenditure will be considered below. 
Figure 1. Great Britain's international accounts, 1870-1915 (year averages, millions of pounds)

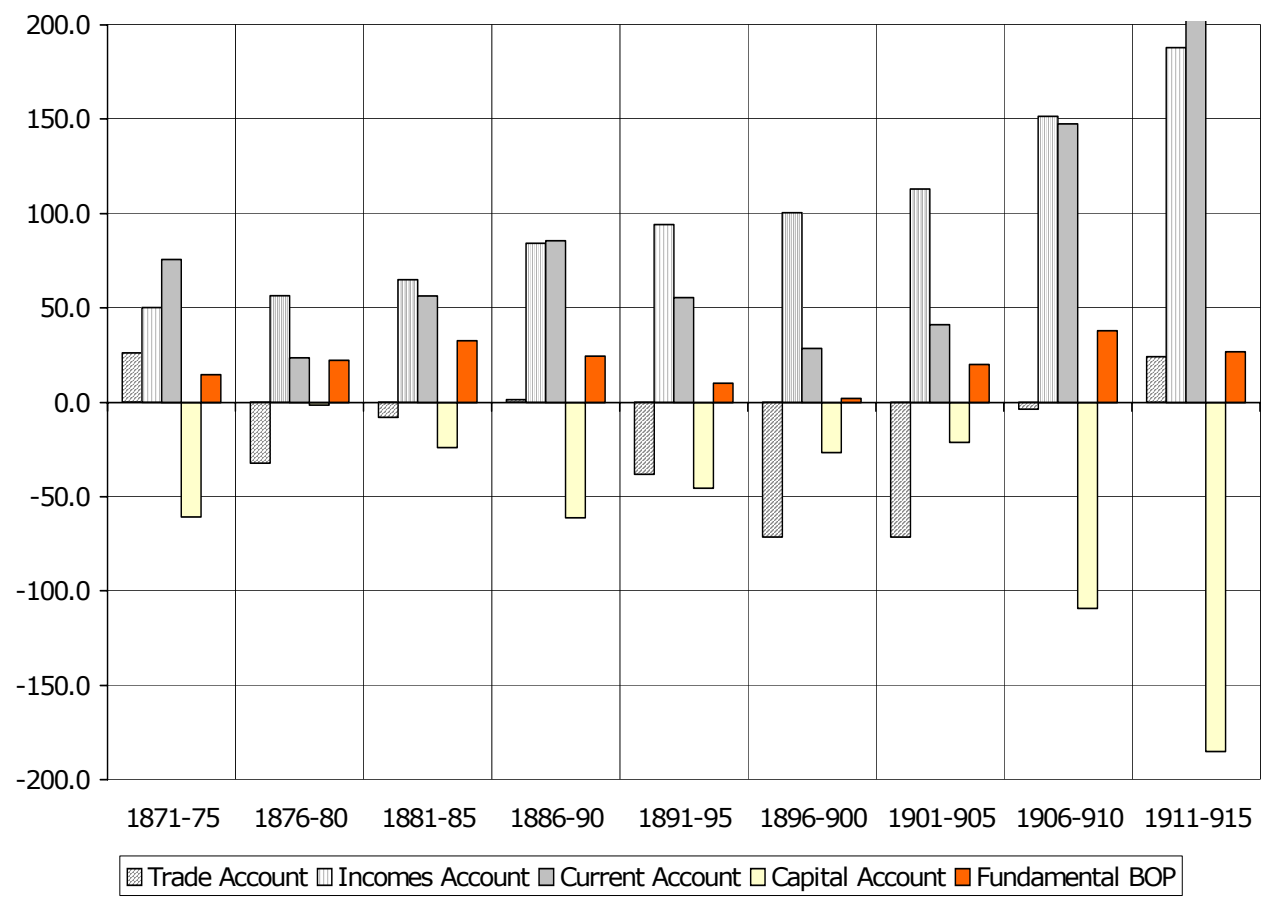

In a long-run perspective, however, the decline of Britain in international trade and her persistent trade deficits were fatal for the British world order. Its economic erosion was due to a number of deeplying causes, prominent among which were obsolescence of technology, unfavourable specialization vis-à-vis emerging competitors in the free Western world, and import-dependent consumption habits. However, also political-economic macro-factors should be considered.

Hobson's analysis of the British Empire (1902) provided one of the earliest and clearest accounts of the "costs of the empire", first, by dispelling the naive idea that empires are always built in the interest of the nation as a whole, and, second, by pointing out how the growing absortion of public expenditure by the foreign affairs apparatus, vis-àvis a declining GDP capacity, set the British economy on an 
unsustainable path. Hobson consistently applied relationship (5) well before its appearance in economic textbooks. According to his data, from 1870 to 1900 public expenditure rose from 61.7 to 128.7 million pounds, with the military share escalating from $31.9 \%$ to $53.5 \%$, - i.e. three and a half times in nominal terms and more than four times in real terms ${ }^{11}$. The increasing costs of international power put the public budget under pressure, eventually forcing Victorian governments to abandon the cornerstones of the liberist tradition by introducing a heavier income taxation system and by resorting to borrowing. Debt financing of the military apparatus rose from almost nil in 1870 to about 50 million pounds before World War I (Hobsbawm (1968), ch. 12). Thus, in modern economic textbooks' terms, the persistent British trade deficits were due to excess domestic real absorption in a vicious circle of upper-class consumption and investment trends sustained by foreign incomes, and of growing excess public expenditure necessary to support the global power that made high consumption, investment and foreign incomes possible. ${ }^{12}$

It is remarkable that this system maintained a high degree of stability, given that its pivot was a chronically dependent country as to real resources. This situation, in fact, raises the question of sustainability: how long can a country live above its means? One stability factor was that Britain was not a debtor but a rentier: the flow of world rent necessary to sustain excess domestic real absorption was, to a great extent, guaranteed. Another factor was the Empire, a twoedged sword by itself. I earlier used the term "vicious circle" to denote the role of military expenditure in the excess absorption mechanism; yet contemporaries would probably view it as a "virtuous circle". Indeed, as the case of India shows, the Empire also offered a large area of administered and protected trade whereby the mother country was able to secure outlets for her goods and to shelter herself against the threats of free trade with emerging Western competitors.

11 Hobsbawm ((1968), tab.43) reports similar figures. It should be noted that the last quarter of the nineteenth century saw a decline of prices in all major industrial countries. In Great Britain the general price index fell by about $25 \%$.

12 For a more detailed and analytical treatment of this process see Tamborini (1992). 
As suggested initially, political power may relax economic constraints or hide them from view. Nonetheless, they eventually become compelling. As is often the case, the alarm bell was rung by a sudden financial crisis. In summer 1914, on the eve of war, the sophisticated network of short-term capitals mastered by the London bankers broke down when, for the first time, London was unable to serve a massive withdrawal of liquid funds in sterling and gold by foreign depositors. Technically, the crisis was overcome in few days, but with hindsight we can say that it marked "the end of an era" (De Cecco (1975), ch. 7). Not only was the pre-war monetary order mortally wounded, but the unsustainability of Great Britain's international political-economic stance became manifest. And after the war, as Keynes emphatically warned in his pamphlets (1931), the obdurate attempts by British governments to restore the vestiges of the past world order played a major role in destabilizing both the international system and their own country.

\subsection{The leadership of the United States after World War II, 1950-1973}

One of the most famous interpretations of the inter-war political, economic and financial instability culminated in the 1929 crash and then in the World War is Kindleberger's major book (1973), the keystone of which is the idea that the collapse of the British world order left a vacuum of political-economic leadership, with no country able to assume the pivotal role that would guarantee an orderly, growth-inducive, network of debtor-creditor positions as well as ensuring the supply of international public goods.

The leading country that presided over the reconstruction of a sustainable world scenario after World War II was the United States. During the 1950s the US took an international economic stance similar to that of Great Britain examined in the previous paragraph - but with some crucial differences. In the aftermath of World War II, like Britain in post-Napoleonic Europe, the US enjoyed a substantial industrial advantage over the rest of the world in terms of fixed capital, infrastructures, production capacity, and financial resources. Absent a formal empire, the role of leader of the victorious Allied Army was quite naturally extended and confirmed in the new confrontation against the 
Communist bloc: economic supremacy went hand in hand with political leadership. Again, the new mix of leadership-cum-partnership on the Western front was sealed by a "monetary pact" quite similar to the goldsterling system centered in London one century before: the gold-dollar system of pegged exchange rates devised at Bretton Woods in 1944.

As can be seen from Table A2 in the Appendix, the gold-dollar system, too, was pinpointed by the dominant country as a world creditor, a young creditor however (see pattern (4)), with capital outflows averaging 500 million dollars per year vis-à-vis trade surpluses of 3.6 billion. Yet, in contrast to the typical creditor-country pattern, the incomes and transfers account was on average negative by 3.6 billion. This left a barely positive current account and an average BOP deficit of 500 million each year, the seeds of a crucial problem in the US international stance. The available data allow us to distinguish, according to international accounting in Table 1, between incomes, largely due to interests and dividends on foreign investments, and unilateral transfers due to private and public non-market payments and obligations. Foreign incomes were indeed consistent with the creditorcountry pattern, showing a yearly positive balance of 1.4 billion dollars. Yet they were outweighed by substantial unilateral transfers abroad of 5 billion, two-thirds of which were government payments. These figures are highly indicative of the US growing international military and nonmilitary commitments ${ }^{13}$. In other words, the US economy, as a consequence of domestic excess capacity, was transferring real and financial resources abroad to the benefit of the reconstruction and development of foreign partners, but the compound effect of foreign investments with military and non-military government commitments was too large relative to net export capacity.

13 Military expenditures abroad averaged at 2.1 billion dollars per year with a fivefold increase in the decade (see Argy (1984), table 3.1). 
Figure 2. The United States' international payments, 1950-73 (billions of dollars)

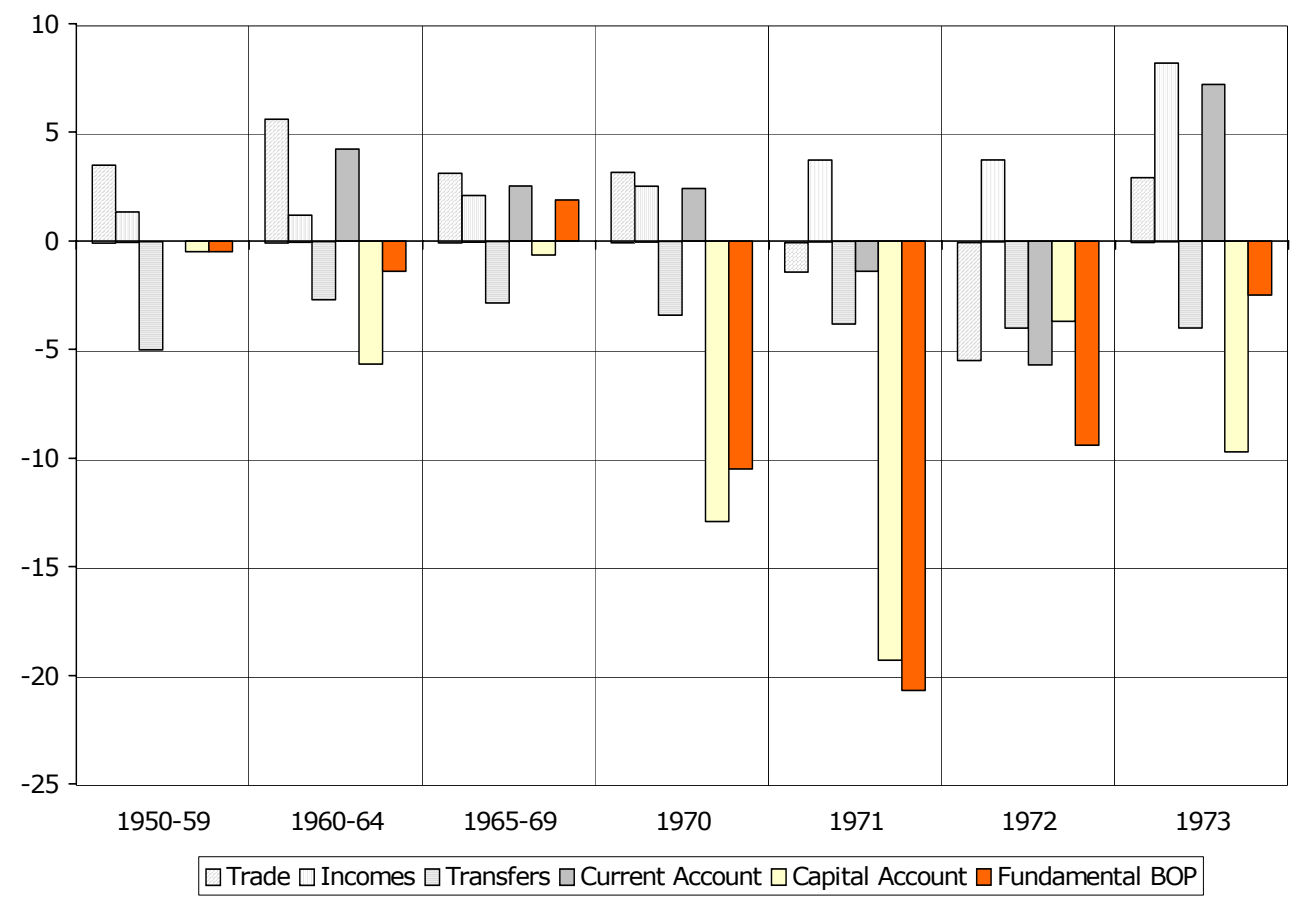

As shown by Table A2 and Figure 2, the 1960s replicated the same pattern in a context of apparent domestic and world stable growth. In reality, in the first half of the decade the fundamental imbalance of US payments dramatically deteriorated, falling to -1.4 billion dollars per year in spite of further improvement in external trade and a positive current account. The BOP deficits were boosted by an upsurge of foreign investments and other capital outflows vis-à-vis an insufficient current account. A critical component of the current account was the rigidity of unilateral transfers. Either a cut in foreign investments and unilateral transfers or a cut in domestic absorption to improve foreign trade were necessary ${ }^{14}$. None of these corrections took

14 The incidence and importance of unilateral transfers in US international payments revived research on a "minor" point of BOP theory, the so-called 
place. Quite the contrary: unlike Imperial Britain, the US economy was set on a path of declining and tendentially negative current account inconsistent with its role as world investor. Nonetheless, apart from minor disturbances, it was only at the end of the 1960s that the golddollar system's crisis was fully understood by markets and governments. The survival of this system for more than twenty years in spite of the pivot country's unsustainable international stance was a variation on the theme of the economic benefits of international power that we have already met in the gold-sterling system.

The solution to the "guns vs. butter" dilemma adopted by the US in the 1950s and 1960s was another international transposition of the classical economic theory of the state: seignorage. Besides levying taxes, the state also has the monopolistic power to print money: indeed, printing money is the alternative means to pay for public expenditures. The US was able to practise seignorage worldwide thanks to the special status of the dollar as world means of payment and reserve. No foreign recipient of dollars would put the Federal Reserve under pressure to convert dollars back into other currencies or gold. Seignorage was one of the benefits of leadership that compensated the leader for the costs of providing defence for all, and at the same time it allowed the exchangerate system to survive. In fact, as Argy (1984) stresses, in the 1950s the world overflow of dollars was probably "demand driven" as the fast growth of international trade generated demand for means of payments in excess of gold supply, and "dollar shortage" was one of the troubles of the time. However, this was no longer the case in the 1960s. Robert Triffin predicted ten years in advance the collapse of the international monetary system brought about by excess US seignorage, i.e. the unsustainable growth of paper dollars in the world relative to the US gold stock (Triffin, 1960). Dollar balances held by non-residents were short-term liabilities of the Fed, which should stand ready to convert them into gold on call. The mounting threat to the convertibility commitment is highlighted by two figures: in 1959 short-term liabilities amounted to 19.4 billion dollars and were 1:1 with gold reserves, in

"transfer problem" concerning whether BOP adjustment mechanisms exist such that a country can honour unilateral transfers: see e.g. Machlup (1963, 1969), Johnson (1956, 1975, 1976), Kindleberger (1968). 
1971 they amounted to 67.8 billions, more than 6 times the value of gold reserves.

The inconsistency between the international political order based on the US leadership and what are now called the "underlying economic fundamentals" exploded in the second half of the 1960s on three fronts: the erosion of trade surpluses, the Vietnam War with the concomitant flood of dollars in the world markets, and the domestic economic downturn of 1968-69. These three developments raised conflicting objectives: sustainability of international commitments would call for a (strong) monetary-fiscal restrictive policy mix domestically, but recovery of the domestic economy would push in the opposite direction. The first objective was (mildly) pursued in the mid-1960s ${ }^{15}$, whereas the second one prevailed in the 1968-69 recession. This change of attitude was read by dollar-holders worldwide as the death certificate of the convertibility commitment, and indeed huge BOP deficits opened up in 1970 and 1971 (-10.5 and -20.7 billion dollars, respectively). Speculative attacks against the dollar were triggered. The official breakdown of the Bretton Woods Agreements occured in August 1971 with a subsequent official devaluation of the dollar by $7.9 \%$. In 1972 the US economy recovered, yet in February 1973 a further 10\% devaluation was necessary, which in fact brought the trade account back to surplus and reduced the BOP deficit. In November, however, the first oil crisis broke out and definitively disrupted the post-war political-economic order.

Overall, in spite of similarities in favourable factors (supremacy in industry and trade, world creditor position, gold-based fixedexchange-rate "monetary pact") and in unfavourable ones (growing external-internal conflicting targets and long-run unsustainability of the BOP constraint) the US leadership model proved to be weaker and shorter-lived than the British imperial system. As a matter of fact, the latter was undermined by the slow erosion of the British world rent, but never was there substantial world payments imbalances. By contrast, the US proved unable, or unwilling, to correct the structural imbalance in her international payments, and blatantly resorted to seignorage

15 The temporary recovery of the BOP reported in Figure 2 was largely due to monetary restrictions raising short-term interest rates and attracting short-term capital inflows (see also Table A2 in Appendix). 
regardless of the "monetary pact". To return to Kindleberger's definition of international leadership, we may conclude that the US broke the rule that a leader must be ready to give priority to international commitments over domestic concerns. Indeed, the end of the coalition pact on which the post-war political-economic order rested was declared as early as 1968 by Charles De Gaulle and his central banker Jacques Rueff, when they announced that the privileges enjoyed by the US thanks to the international role of the dollar were "extravagant" and "no longer acceptable".

\section{Global power and global finance}

The US retreated from international commitments and organized exercise of power after the events described in the previous section. Not surprisingly, neoconservatives are extremely critical of the lack of a grand view and of the piecemeal approach in foreign affairs of the 1970s, for which they indict Richard Nixon and Henry Kissinger, let alone subsequent Administrations. This criticism seems unaware of the collapse of the economic conditions underlying the US leadership, and of the advent of conditions unfavourable to any other possible design of global governance. It is worth focusing on one of these conditions, which the neoconservative view seems unable to fully comprehend: in a capitalist system, the exercise of international political power, no matter how large, is never fully unconstrained. I stressed at the outset that a country's international political stance is feasible as long as it is consistent with a sustainable international economic pattern. Both the historical experiences examined above have shown that, although the extent of international power may relax economic constraints, they are nonetheless binding in the long run. This is unavoidable if international power is to be exerted within a frame of free market relationships with partners.

This general principle has been gaining further cogency in the last two decades: on the doctrinal side thanks to the advent of the socalled "New Political Economics", which advocates that governments be subject to the "market constituency" as the safeguard of the economic rationality of their choices (a conservative doctrine itself, by the way); and on the economic side as a consequence of the general phenomenon 
of market globalization. Compared to the early post-war decades, when limits and controls on international transactions were much stricter and the driving capacity of markets by politics much stronger, nowadays the market conditioning of international political choices is likely to be strengthened. In short, global power has to come to terms with global finance.

Prior to the open endorsement of the neconservative doctrine by G. W. Bush, the US had already experienced the implications of financial globalization for international politics with the "Star Wars" programme under the Reagan Administration. President Reagan took office in 1981 and his economic programme was based on dismantling market protections and limitations, on the one hand, and on strong fiscal expansion through low taxes and high strategic expenditure, on the other. High strategic (military and non-military) expenditure also reflected an international political choice to restore the US to its role as world leader in the final attack against the Communist bloc. The rationale of the "Star Wars" programme was essentially to raise the cost of mutual deterrence so enormously as to shatter the USSR economy. In our metaphor, the "butter VS. guns" alternative would have strangled the USSR, whereas the US economy would have enjoyed "more butter and more guns". Was this design accomplished? Who actually paid for the "Star Wars" programme? The answers to these questions provide a clear exemplification of the principles put forward so far.

First of all, the Reagan fiscal programme produced a sequence of large deficits escalating from $2.1 \%$ of GDP in 1981 to $5.2 \%$ in 1985 to return to $2.8 \%$ in 1988 (see Table 2). In the eight years of the two Reagan Administrations, defence expenditure rose costantly from 157 billion dollars in 1981 to 290 in 1988, and it reached the historical peace-time peak of $6.2 \%$ of GDP in 1986. As explained in section 2 , the international impact of the government budget can be viewed in real as well as financial terms. In real terms, it adds to the domestic absorption of resources of the private sector and hence co-determines the trade balance with the rest of the world (relation (5)). Since the private sector's absorption was almost in balance or in surplus, the US experienced the so-called "twin deficits" phenomenon - that is, trade deficits vis-à-vis government deficits - as can be seen in Figure 3. 
Figure 3. US "twin deficits" and the real value of the dollar, 1980-02 (\% of GDP)

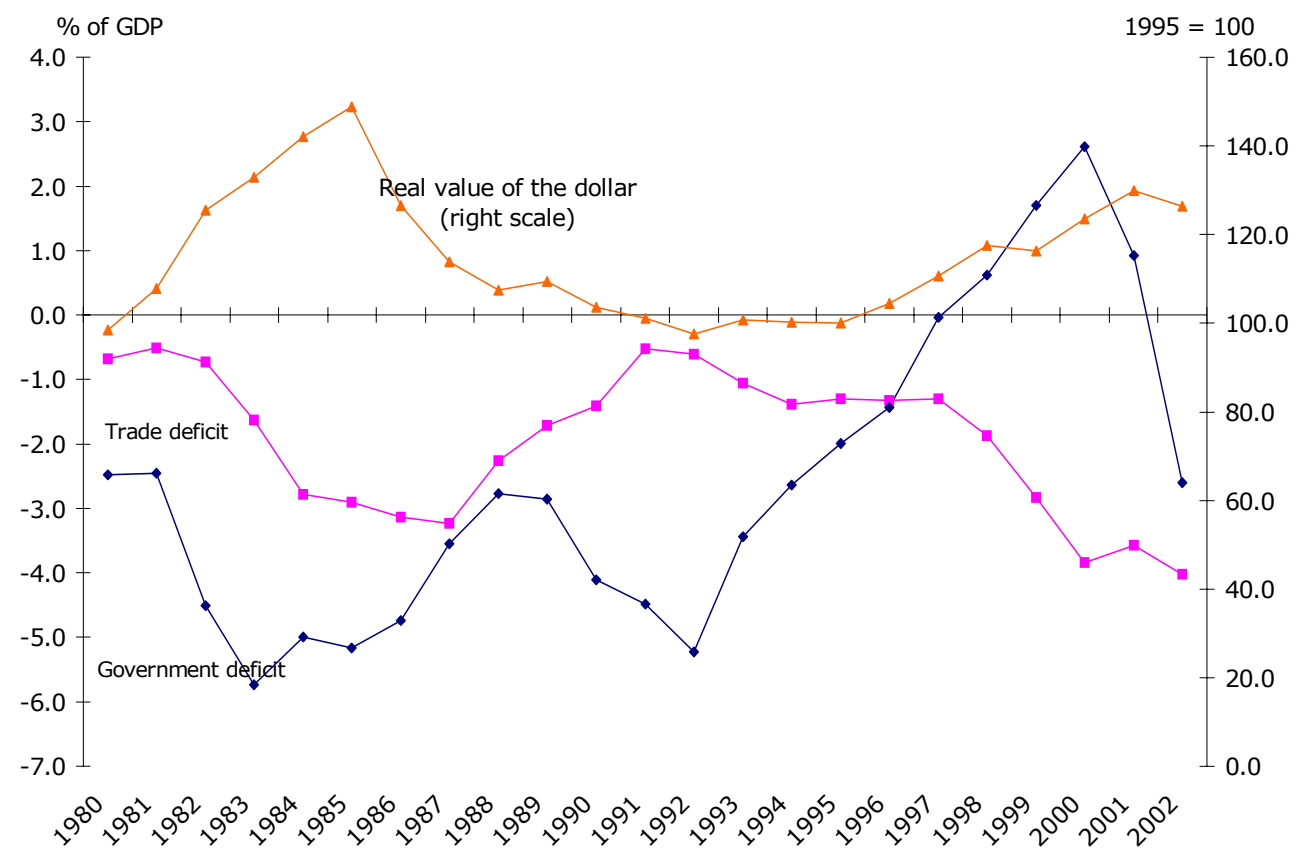

In financial terms, as shown by relationship (6), fiscal deficits matter because they determine the borrowing requirement of the public sector; given net lending or borrowing (the saving-investment balance) of the private sector, the difference should result in net lending or borrowing with the rest of the world.

Figure 4 reproduces the US financial accounts from 1981-88. The public sector borrowing requirement rose from 3.1 of GDP in 1981 to 9.3 in 1986. In spite of a sustained net lending capacity of the private sector (excess of private saving over private investment) amounting to around $5 \%$ of GDP, the consequence was an increasing external borrowing requirement which peaked at 5\% of GDP in 1986. 
Figure 4. US financial accounts, $1980-02$ (\% of GDP)

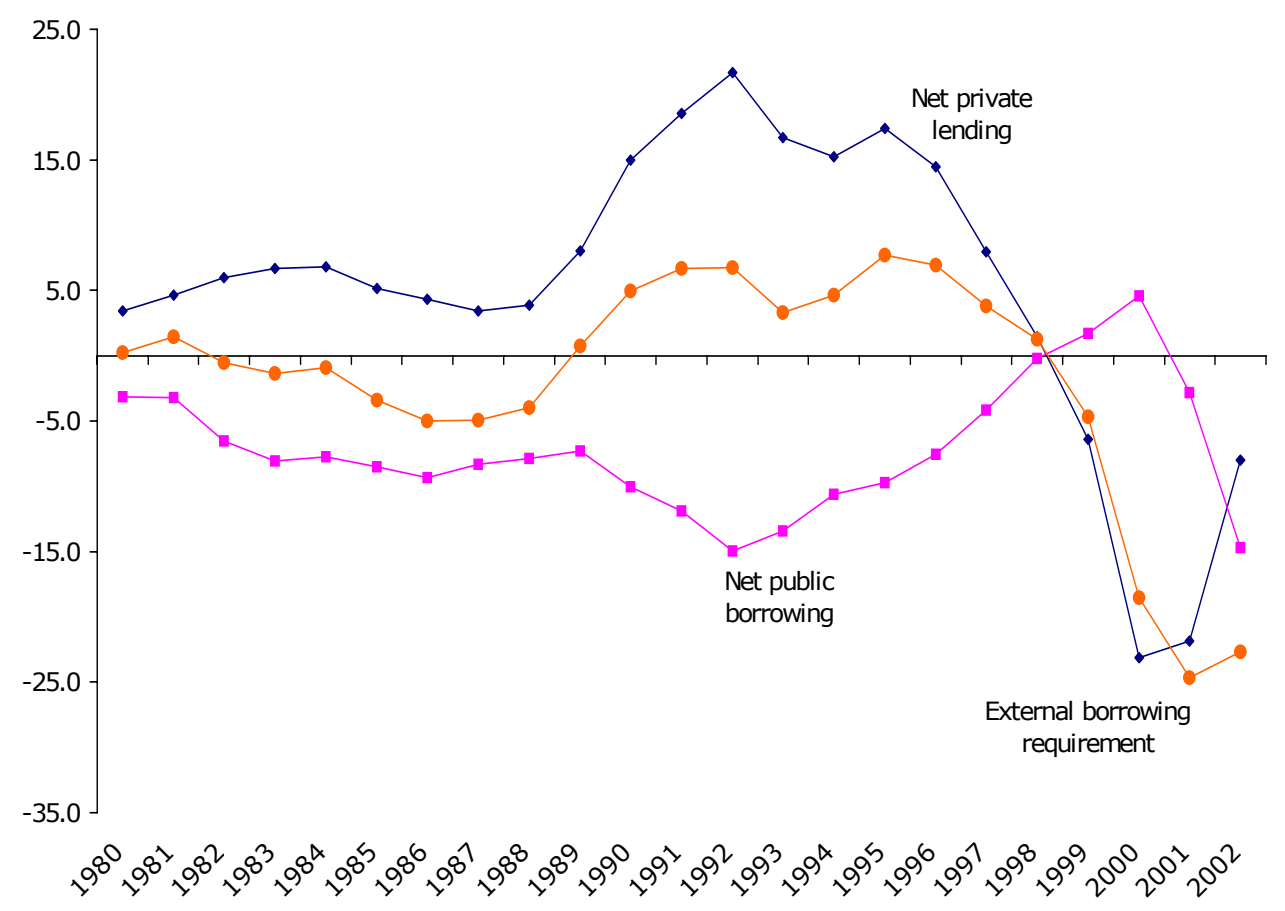

These real and financial tendencies set in motion by the US fiscal policy were eventually reflected in international accounts (see table A3 in the Appendix). Thus, the most striking feature of the first attempt to return to global power after the crisis of the 1970s, in the new context of global finance and floating exchange rates, was that the US had to take a typical world debtor position. In fact, trade deficits were covered by huge capital inflows, with a constant trend of unilateral transfers barely compensated by declining foreign incomes. Foreign incomes were declining as a consequence of the growing foreign debt service generated by external borrowing and by high interest rates paid by US Treasury bonds. The US had net foreign assets of 356 billion dollars in 1980, 
which were reduced to 10.4 in 1988 , and then turned into net liabilities from 1989 onwards (see Figure 5).

Figure 5. US Net Foreign Position, 1980-2002 (billions of dollars)

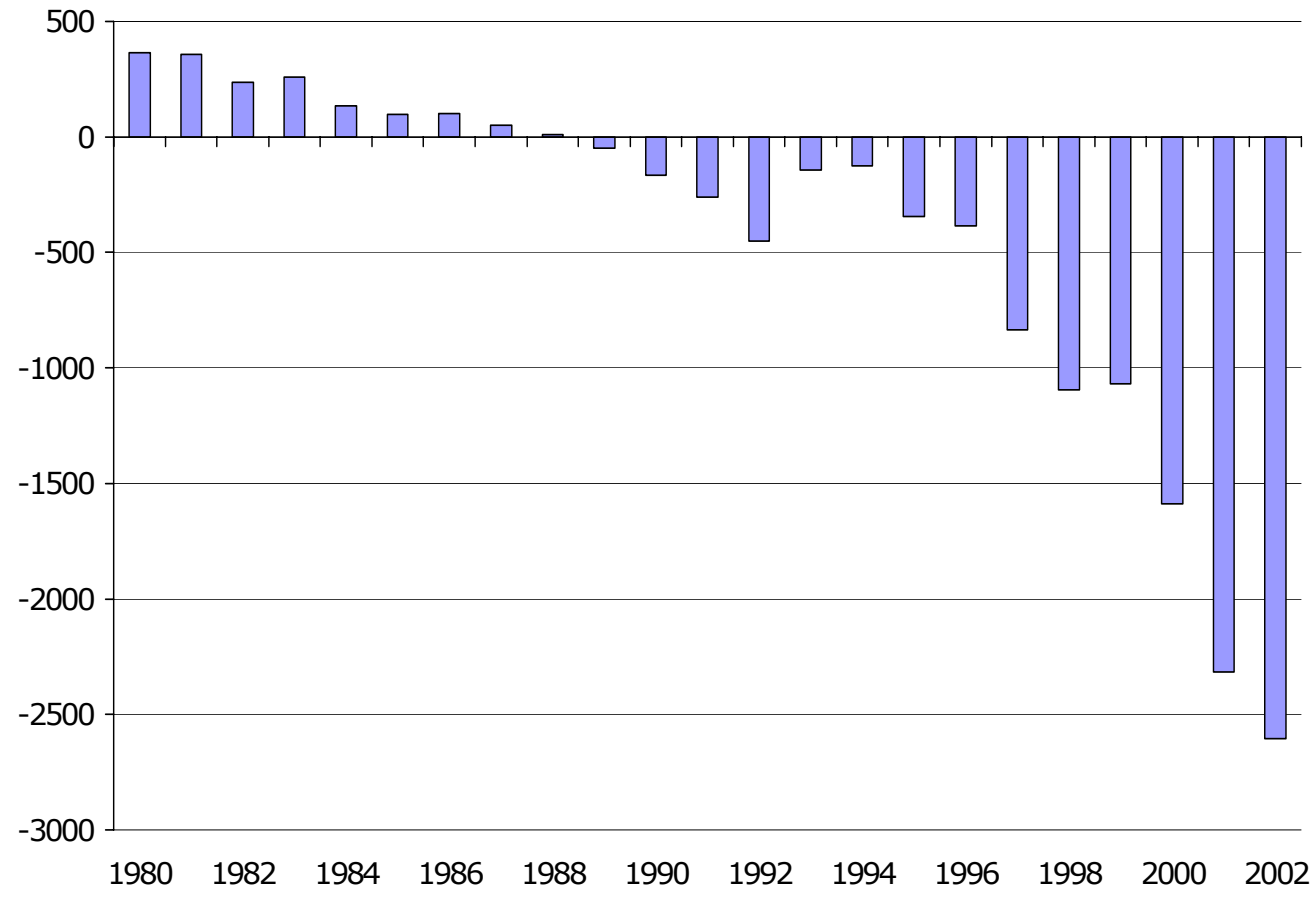

The interesting question raised by the Reagan parable is whether the world political-economic leader can be a debtor. The lesson may be relevant to Bush as well. Recourse to global debt by the Reagan Administration was an alternative to seignorage ${ }^{16}$ in the attempt to by-

16 An important element in the picture is monetary policy. The new President of the Federal Reserve appointed by Reagan, Paul Volker, launched a U turn in monetary policy towards neo-monetarist principles. The growth rate of the money stock as a means to curb inflation became the pivot of the Fed's policy. Volker introduced severe monetary restriction in 1981, which resulted in a slowdown of inflation with a sharp recession in $1982(-2.1 \%$ of GDP). Subsequently, this strict adherence to the monetarist doctrine was relaxed, but 
pass the domestic "butter vs. guns" trade-off by inducing partners to share the military effort. Yet, as stressed by Kindleberger ((1984), chs. $12,16)$, it is a recurrent faulty idea that the best financial policy to pay for wars is debt, on the illusion that this dispenses with the need to raise taxes. Debt is only a means to shift higher taxes, or lower nonmilitary expenditures, to the future: "[recourse to] debt is irrelevant to the question as to whether the country [can], or [cannot] pay for the war", and to this effect "one has to take into account repercussions throughout the system (Kindleberger (1984), p.172)). The system, for a global player, is the world. As explained in section 2, a world debtor has to pay higher interest rates and/or appreciate its currency in order to induce foreign lenders to accommodate increasing shares of its liabilities in their portfolios. From 1981 to 1985 the US recorded the most dramatic peace-time increase in nominal and real interest rates. In the same period, the dollar appreciated by $51.2 \%$ in real terms vis-àvis the US trading partners' currencies. The other side of the coin was that high interest rates worsened the income account, while the strong dollar worsened the trade account, thereby widening the external borrowing requirement in a vicious circle. As to lenders, the world expansionary effect of US trade deficits was outweighed by the contractionary effect of financial resources absorption and high interest rates. The overall negative impact of the new US international stance was felt both in Europe, which experienced a twin spike in interest rates and unemployment (Fitoussi and Phelps (1988)), and in the developing countries, which were no longer able to meet their external dollar-denominated debt services (Strange (1998)) 17 .

The blatant financial unsustainability of the "Star Wars" programme on the one hand, and its negative effects on the partner economies on the other, disrupted the US new international stance in a handful of years. In June and October 1985 two meetings of the major

the Fed ceased to be a lender of last resort for the government, which was forced to finance budget deficits by issuing debt.

17 Remember that, by contrast, in the post-war period US international lending and trade deficits, albeit structurally unbalanced, played a crucial role in recovering and sustaining world economic activity in a context of monetary stability, to the general benefit of partners. 
industrialized countries "talked the dollar down", thereby putting an end to the world lending-to-America frenzy and, at the same time, to the tale that America could do by herself. The legacy of Reagan's global war finance experiment was the devastating third-world debt crisis of 198285 and, as a final coup de theatre, the Wall Street crash of October 1989 .

The numerous analogies between Reagan's and G.W. Bush's global war finance programmes are evident. Both have taken place in a context of weak domestic economy, fiscal expansionary policies and large reliance on external debt. While aware of the pitfalls of historical analogies as guidance to future developments, it is nonetheless worth examining in greater detail the initial conditions of the two programmes. This task is helped by Table 2, which summarizes a few selected economic indicators of the two Administrations vis-à-vis the previous Administration. 
Table 2. Reagan and G.W. Bush Administrations. Selected indicators Defence Defence Budget Debt Foreign GDP $\%$ total \% GDP \% GDP \% GDP \% total growth exp.

Reagan

\begin{tabular}{rrrrrrr}
\hline Prev. Adm. ${ }^{1}$ & 23.1 & 4.4 & -2.2 & 27.2 & 19.2 & 3.4 \\
\hline Prev. year & 22.7 & 4.8 & -2.5 & 26.6 & 17.6 & -0.2 \\
\hline 1981 & 23.2 & 5.1 & -2.5 & 26.6 & 16.5 & 2.5 \\
\hline 1982 & 24.8 & 5.7 & -4.5 & 30.6 & 15.1 & -2.1 \\
\hline 1983 & 26.0 & 6.0 & -5.7 & 33.5 & 14.2 & 4.3 \\
\hline 1984 & 26.7 & 5.8 & -5.0 & 35.3 & 15.0 & 7.3 \\
\hline 1985 & 26.7 & 6.1 & -5.2 & 38.3 & 14.1 & 3.8 \\
\hline 1986 & 27.6 & 6.2 & -4.7 & 41.1 & 14.5 & 3.4 \\
\hline 1987 & 28.1 & 6.0 & -3.5 & 41.6 & 15.3 & 3.4 \\
\hline 1988 & 27.3 & 5.7 & -2.8 & 41.4 & 17.3 & 4.2 \\
\hline Bush & & & & & & \\
\hline Prev. Adm.1 & 16.4 & 3.1 & 1.2 & 41.4 & 32.5 & 4.2 \\
\hline Prev. Year & 16.5 & 3.0 & 2.6 & 35.0 & 30.3 & 3.8 \\
\hline 2001 & 16.4 & 3.0 & 0.9 & 33.9 & 31.0 & 0.3 \\
\hline 2002 & 17.3 & 3.4 & -2.6 & 35.1 & 33.2 & 2.5 \\
\hline 2003 & 17.6 & 3.5 & -3.7 & 37.3 & n.a. & 2.5 \\
\hline 1
\end{tabular}

1Four year average 
Table 2 (cont.d).

\begin{tabular}{|c|c|c|c|c|c|}
\hline & Inflation & $\begin{array}{l}\text { Long int. } \\
\text { rate }\end{array}$ & REER $^{1}$ & $\begin{array}{l}\text { Trade } \\
\text { account } \\
\% \text { GDP }\end{array}$ & $\begin{array}{c}\text { NFA }^{2} \\
\% \text { GDP }\end{array}$ \\
\hline \multicolumn{6}{|l|}{ Reagan } \\
\hline Prev. Adm. ${ }^{1}$ & 7.9 & 8.6 & 101.7 & -1.1 & 16.2 \\
\hline Prev. year & 9.2 & 10.8 & 98.4 & -0.7 & 13.2 \\
\hline 1981 & 5.1 & 12.9 & 107.9 & -0.5 & 11.5 \\
\hline 1982 & 5.7 & 12.2 & 125.5 & -0.7 & 7.3 \\
\hline 1983 & 6.0 & 10.8 & 132.9 & -1.6 & 7.4 \\
\hline 1984 & 5.8 & 12.0 & 142.1 & -2.8 & 3.4 \\
\hline 1985 & 6.1 & 10.8 & 148.8 & -2.9 & 2.3 \\
\hline 1986 & 6.2 & 8.1 & 126.5 & -3.1 & 2.3 \\
\hline 1987 & 6.0 & 8.7 & 113.9 & -3.2 & 1.1 \\
\hline 1988 & 5.7 & 9.0 & 107.5 & -2.3 & 0.2 \\
\hline \multicolumn{6}{|l|}{ Bush } \\
\hline Prev. Adm. ${ }^{1}$ & 1.7 & 5.8 & 117.0 & -2.5 & -12.8 \\
\hline Prev. Year & 2.1 & 5.5 & 123.6 & -3.8 & -16.3 \\
\hline 2001 & 2.4 & 5.3 & 129.9 & -3.6 & -23.1 \\
\hline 2002 & 1.1 & 5.2 & 126.4 & -4.0 & -25.1 \\
\hline 2003 & 1.9 & 4.8 & n.a. & n.a. & n.a. \\
\hline \multicolumn{6}{|c|}{$\begin{array}{l}1 \text { Four year average } \\
2 \text { Real effective exchange rate }(1995=100) \\
{ }^{3} \text { Net Foreign Assets }\end{array}$} \\
\hline $\begin{array}{l}\text { Source: Ecor } \\
\text { International }\end{array}$ & $\begin{array}{l}\text { Report } \\
\text { incial St }\end{array}$ & $\begin{array}{l}\text { the Pres } \\
\text { tics, CD- }\end{array}$ & Wash & n & 3; IMF， \\
\hline
\end{tabular}


To begin with, let us point out possibly more favourable conditions. First and foremost, Bush has inherited healthier public finances than Reagan: the overall budget was in surplus in 2000, public debt was diminishing, and defence expenditure was relatively low, in relation both to total expenditure and to GDP. These conditions allow greater room for manoeuvre than that available to the Reagan Administration. The impact of Bush's military programme seems at the moment to be less dramatic than Reagan's: even in 2003, the year of the Iraq war, defence expenditure (380 billion dollars) is estimated to reach $17.6 \%$ of total expenditure and $3.5 \%$ of GDP, 18 well below the peaks of $28 \%$ and $6 \%$, respectively, in 1986-87. The overall budget deficit is expected to be $3.7 \%$ of GDP in 2003 and between 4.5 and $5 \%$ in 2004, whereas it reached $5.7 \%$ in 1983.

However, military and strategic expenditure during the Reagan Administration was almost entirely channelled to domestic research and investment aims, whereas the Bush Administration's programme is far more complex and ambitious. It implies not only funding the domestic strategic apparatus, but also engaging in external military operations as well as non-military aids and transfers, the cost of which is not completely reflected in the defence budget and is still largely to be determined. Projections are extremely volatile and unreliable. As an example, prior to the Iraq war, the economist William Nordhaus 19 estimated that the military and non-military federal costs of the operation might range from 121 of 1595 billion dollars, depending on the length and difficulty of the war and post-war operations. The Administration itself has announced a target for the defence budget of 451 billion dollars in 2007 , with total expenditure amounting to 2144 billion dollars from 2002 to 2007. Assuming a 5\% yearly increase in nominal GDP, the US would end up with defence expenditure absorbing about $5 \%$ of GDP in 2007, a figure in line with its order of magnitude in the 1980s. Overall, one may expect that the fiscal impact of the Bush programme will eventually be comparable with that of Reagan's.

18 In 1991-92, after the first Iraq war, defence reached $21.8 \%$ of total expenditure and $4.8 \%$ of GDP.

19 New York Review of Books, December 5, 2002. 
Let us now turn to a list of less favourable conditions than those faced by the Reagan Administration. These essentially affect the US borrowing capacity, and hence the long-term sustainability of the neoconservative programme. In this respect, Bush has inherited an international financial position of the country that was much harder, for his own purposes, than that inherited by Reagan. First of all, in 1980 the US had net claims towards the rest of world of 378.7 billion dollars; at the end of the 1990s the US was one of the world's largest debtors, with net liabilities amounting to 1588.7 billion dollars, $16.3 \%$ of GDP (see Figure 5). The US financial and international accounts in the second half of the 1990s displayed a pattern similar to that of the 1980s (see Figure 3 and Figure4) except that the driving force was not government deficits but the longest private investment and consumption cycles in post-war history. The private saving-investment balance has been shrinking since 1995 and has turned to negative since 1998. With back-paddling government deficits, massive external borrowing has nonetheless been necessary to sustain the "new economy" investment bubble. High expected returns on stocks and capital inflows have set the dollar on a robust appreciation path; parallely, the trade account, after the recovery of the late 1980s, has pointed again towards larger and larger deficits, reaching the post-war record of 375 billion dollars (3.8\% of GDP) in 2000. Large interest payments owed to foreign investors have added to trade imbalances to produce the concomitant current-account negative record of 421.3 billion dollars (4.3\% of GDP). In the first three years of the Bush Administration, these tendencies have worsened further, with the government budget again taking the lead of financial imbalances. Thus, the neoconservative programme not only hinges on a replica of Reagan's idea of global war finance, but it also presumes that the replicant can be a massive world debtor with yawning current-account deficits.

The forces that can play against a world debtor maintaining the role of world power for a long time have already been discussed. As the foregoing analysis shows, from this viewpoint the Bush Administration has much less room for future manoeuvre than the Reagan Administration. International financial markets and policy-makers have already set in motion the adjustment process of the US external position required by a mature debtor. The Fed keeps interest rates low, capital inflows are slowing down, and the dollar is depreciating to the 
effect of correcting the current-account imbalances. At the same time, the domestic absorption of real as well as financial resources should be reduced, which requires less consumption, more saving and balanced fiscal budgets. Thus, the US economy is now being driven through the same phase that followed the Reagan era in the late 1980s and early 1990s: that is, the adjustment process that had to be managed by Bush sr. (see Figure 3 and Figure 4). Viewed in this perspective of financial phases, Bush jr.'s policy is, literally, "anachronistic".

It is highly unlikely that the mature-debtor phase of the US economy can be inverted, and any attempt to move in that direction would be fraught with danger to international stability. As after 1985, the "must" of world markets and policy-makers is now the so-called "soft landing" of the dollar. That is to say, depreciation of the dollar, reduction of capital inflows and improvement of the current account must be carefully tuned so that the mutual adjustment of the three variables occurs gently and smoothly. Along this path, little room is left for fiscal deficits. It is true that public debt is less than $15 \%$ of overall US foreign liabilities (but more than $30 \%$ of it is held abroad). Nonetheless, given the general tendency to reduce dollar-denominated assets in world portfolios, large loans to Washington would require a sharp increase in interest rates or, alternatively, massive monetization of federal deficits by the Fed - i.e. seignorage once again. The first alternative is precluded by three considerations. 1) High interest rates would create recessionary conditions and would defeat the effect of tax cuts which are the hallmark of Bush's programme. 2) They would produce a fall in stock prices, which on the one hand would amplify recessionary conditions while on the other might trigger capital flights and attacks against the dollar. 3) They would also reduce the value of US T-bonds in world portfolios, and massive foreign sales of T-bonds would soon make financial and monetary policy in Washington unmanageable.

The alternative to high interest rates represented by seignorage encounters no less serious obstacles. 1) Systematic monetization of fiscal deficits is nowadays strictly inhibited by central banking doctrines. Though the Fed has a tradition of pragmatism and flexbility, this policy would represent a U turn in its strategy and reputation, setting the clock back to the 1960s and 1970s, when, as explained previously, pro- 
seignorage US monetary policy was seen as one of the causes of the collapse of the world monetary system. 2) Consequently, fast growing money supply dictated by fiscal deficits would hardly be consistent with the "soft landing" strategy. Financial markets might read proseignorage monetary policy as signalling that fiscal policy is unsustainable and react by selling T-bonds and speculating against the dollar.

It seems fair to conclude that the smooth correction of the US mature debtor position now in progress sets fiscal policy on a narrow path, probably too narrow for the global war finance operations required by the neoconservative programme. Moreover, since politics has not completely disappeared from the stage of world finance, it should also be borne in mind that a substantial share of the US T-bonds circulating in the world is bought and held by institutional investors in Japan, China and "old Europe", that is to say countries which are quite moderately favourable to, or openly against, Bush's foreign policy. Thus, in spite of the neoconservative ostentation of unilateralism, the new US international political stance should to some extent rely upon the financial benevolence of its opponents.

\section{Concluding remarks}

Current analyses of the neoconservative turn in US foreign policy tend to neglect its economic requirements and consequences. This is probably due to their long-run and uncertain nature, which stretches far beyond the accounting of the Afghan and Iraq campaigns. Yet one expects the foreign policy choices of a global power to be made with a clear understanding of their probable long-run economic costs and of their sustainability.

The assessment of these economic implications presented in this paper has focused on the long-run sustainability of international political choices as determined by the ensuing international economic pattern of the country. The success of candidates to world governance in a frame of free market relations does not only depend on the extent of their political will or power. The fiscal counterpart of governments' foreign policy interacts with the private sector's saving and investment choices, co-determining the evolution of external trade and of external 
borrowing or lending. Comparison with the historical experiences of world governance of pre-World-War-I Britain and post-World-War-II America has shown that financial sustainability of borrowing or lending positions is a crucial factor in the long run, and that no international political stance can withstand the "hard laws of markets" for long.

We have seen that those systems of world governance remained sustainable as long as 1) both countries were world creditors, 2) their international commitments were contained within not too large fiscal imbalances, 3) their international economic positions were beneficial to their partners as well. America was still world creditor when President Reagan launched his global war finance venture, which however transformed the Americans into world debtors. The instrinsic fragility of that (comparatively) short-lived experience lay in the violation of all three previous successful conditions. President Bush's fiscal counterpart of his foreign policy looks very similar to Reagan's, with the major incovenience that he took office when the country was already the largest world debtor. As a consequence, Bush's policy mix is confronted by two extremely difficult hurdles on international economic grounds. The first is that the US, in spite of the rhetoric of uncompromised unilateralism, is a country under external financial dependence, with the opponents of its foreign policy in possession of most of the financial means. The second is that, as a matter of fact, international financial markets and policy-makers (Fed included) are already driving the US economy along an adjustment path where little room is left for the large global war finance operations required by the neoconservative programme. 


\section{References}

Ardant G. (1976), Histoire financiere de l'antiquité a nos jours, Paris, PUF.

Argy V. (1984), The Postwar International Money Crisis. An Analysis, London, Allen \& Unwin.

Arrighi G. (1978), Geometria dell'imperialismo, Milano, Feltrinelli.

De Cecco M. (1975), Money and Empire: The International Gold Standard 1890-1914, Oxford, Blackwell; Italian ed., Moneta e impero. Il sistema finanziario internazionale dal 1890 al 1914, Turin, Einaudi, 1979.

Feis H. (1930), Europe the World Banker 1870-1914, Harvard, Harvard University Press.

Fitoussi J.P., Phelps E.S. (1988), The Slump in Europe, Oxford, Blackwell.

Gilpin R. (2003), "The Nature of Political Economy", in Goddard C.P., Gormin P., Dash K.C. (eds.), International Political Economy, London, Palgrave.

Hobsbawm E.J. (1968), Industry and Empire, London, Weidenfeld \& Nicolson.

Hobson J. (1902), Imperialism. A Study, 2nd ed., London, Allen \& Unwin, 1938.

Johnson H.G. (1956), "The Transfer Problem and Exchange Rates Stability", in International Trade and Economic Growth, London, 1958.

Johnson H.G. (1975), "The Classical Transfer Problem: An Alternative Formulation", Economica, 65, pp.710-731.

Johnson H.G. (1976), "Notes on the Classical Transfer Problem", The Manchester School, 44, pp. 538-563.

Keohane R. (1980), "The Theory of Hegemonic Stability and Changes in International Economic Regimes, 1967-1977", in Goddard C.P., Gormin P., Dash K.C. (eds.), International Political Economy, London, Palgrave.

Keynes J.M. (1931), Essays in Persuasion, London, Macmillan.

Kindleberger C.P. (1968), International Economics, Homewood, 4th ed.

Kindleberger C.P. (1973), The World in Depression 1929-1939, London, Allen \& Unwin. 
Kindleberger C.P. (1976), "Systems of International Economic Organization", in Calleo P. (ed.), Money and the Coming World Order, New York, Harpers \& Row.

Kindleberger C.P. (1981), "Dominance and Leadership in the International Economy. Exploitation, Public Goods and Free Rides", in The International Economic Order. Essays on Financial Crisis and International Public Goods, New York, Basic Books, 1988.

Kindleberger C.P. (1984), A Financial History of Western Europe, London, Allen \& Unwin.

Machlup F. (1963), "The Transfer Problem Revisited", in International Monetary Economics, London, Macmillan, 1965.

Machlup F. (1969), "Il 'transfer gap' degli Stati Uniti", Moneta e Credito, 22, pp. 137-151.

Persson T., Tabellini G. (1990), Macroeconomic Policy, Credibility and Politics, Chur, Harwood Academic Publishers.

Strange S. (1998), Mad Money, Manchester, Manchester University Press.

Tamborini R. (1992), Il trasferimento mondiale delle risorse. Un approccio finanziario ai pagamenti internazionali, Firenze, La Nuova Italia.

Triffin R. (1960), Gold and the Dollar Crisis, New Haven.

Triffin R. (1969), Our International Monetary System, New York, Random House.

Williams D. (1968), "The Evolution of the Sterling System", in Whitlesley C.R., Wilson J.S.G. (eds.), Essays in Money and Banking in Honour of R. S. Sayers, Oxford, Clarendon Press. 


\section{Appendix}

Table A1. Great Britain's international payments, 1870-1915 (millions of pounds; selected items, year averages)

\begin{tabular}{|c|c|c|c|c|c|c|c|c|}
\hline & $1871-75$ & $1876-80$ & $1881-85$ & $1886-90$ & $1891-95$ & 1901-05 & $1906-10$ & 1911-15 \\
\hline TRADE ACCOUNT (a) & 25.6 & -32.6 & -8.3 & 1.2 & -38.5 & -71.8 & -3.9 & 23.8 \\
\hline Merchandise, net & -19.3 & -78.9 & -56.4 & -44.3 & -84.4 & -115.0 & -79.1 & -61.3 \\
\hline Services, net & 44.9 & 46.3 & 48.1 & 45.5 & 45.9 & 43.2 & 75.2 & 85.1 \\
\hline INCOMES ACCOUNT (a) & 50.0 & 56.3 & 64.8 & 84.2 & 94.0 & 113.0 & 151.4 & 188.0 \\
\hline \multicolumn{9}{|l|}{ CAPITAL ACCOUNT } \\
\hline Foreign investments (b) & -61.0 & -1.7 & -23.9 & -61.1 & -45.6 & -21.3 & -109.5 & -185.0 \\
\hline
\end{tabular}




\begin{tabular}{|c|c|c|c|c|c|c|c|}
\hline & $\begin{array}{r}1950-59 \\
(a)\end{array}$ & $\begin{array}{r}1960-64 \\
(a)\end{array}$ & $1965-69$ & 1970 & 1971 & 1972 & 1973 \\
\hline 1.TRADE ACCOUNT & 3.6 & 5.7 & 3.2 & 3.2 & -1.4 & -5.5 & 3.0 \\
\hline Merchandise, net & $\ldots$ & 5.4 & 2.6 & 2.6 & -2.3 & -6.4 & 0.9 \\
\hline Services, net & $\ldots$ & 0.3 & 0.5 & 0.6 & 0.9 & 0.9 & 2.1 \\
\hline $\begin{array}{l}\text { 2.INCOMES \& } \\
\text { TRANSFERS ACC. }\end{array}$ & -3.6 & -1.5 & -0.7 & -0.8 & 0.0 & -0.2 & 4.2 \\
\hline Incomes & 1.4 & 1.2 & 2.2 & 2.6 & 3.8 & 3.8 & 8.2 \\
\hline Unilateral Transfers & -5.0 & -2.7 & -2.8 & -3.4 & -3.8 & -4.0 & -4.0 \\
\hline $\begin{array}{l}\text { 3. CURRENT ACCOUNT } \\
(1+2)\end{array}$ & 0.0 & 4.2 & 2.5 & 2.4 & -1.4 & -5.7 & 7.2 \\
\hline 4.CAPITAL ACCOUNT & -0.5 & -5.7 & -0.7 & -12.9 & -19.3 & -3.7 & -9.7 \\
\hline Foreign investments & $\cdots$ & -4.3 & -3.8 & -6.4 & -9.1 & -6.2 & -6.9 \\
\hline Short term capitals & $\cdots$ & -1.3 & 3.2 & -6.5 & -10.2 & 2.5 & -2.8 \\
\hline $\begin{array}{l}\text { 5.FUNDAMENTAL BOP } \\
(3+4)\end{array}$ & -0.5 & -1.4 & 1.9 & -10.5 & -20.7 & -9.4 & -2.5 \\
\hline
\end{tabular}


Table A3. United Sates' international payments and net foreign position, 1980-90 (billions of dollars)

\begin{tabular}{|c|c|c|c|c|c|c|c|c|c|c|c|}
\hline & 1980 & 1981 & 1982 & 1983 & 1984 & 1985 & 1986 & 1987 & 1988 & 1989 & 1990 \\
\hline 1.TRADE ACC. & -18.9 & -15.7 & -23.5 & -57.1 & -108.3 & -121.1 & -138.5 & -151.7 & -114.7 & -93.1 & -80.9 \\
\hline Merchandise,net & -25.5 & -28.0 & -36.5 & -67.1 & -112.5 & -122.2 & -144.6 & -159.2 & -126.6 & -117.0 & -110.3 \\
\hline Services, net & 6.6 & 12.4 & 13.0 & 10.0 & 4.2 & 1.1 & 6.1 & 7.6 & 12.0 & 23.92 & 29.41 \\
\hline $\begin{array}{l}\text { 2.INCOMES \& } \\
\text { TRANS. ACC. }\end{array}$ & 22.1 & 24.9 & 20.3 & 21.3 & 17.9 & 4.8 & 0.2 & 0.9 & 5.1 & -6.0 & -4.7 \\
\hline Incomes & 29.6 & 32.4 & 29.2 & 30.8 & 30.0 & 19.8 & 15.5 & 14.3 & 18.7 & 19.8 & 28.56 \\
\hline Unilateral Transf. & -7.5 & -7.5 & -8.9 & -9.5 & -12.1 & -15.0 & -15.3 & -13.4 & -13.6 & -25.8 & -33.2 \\
\hline $\begin{array}{l}\text { 3.CURRENT } \\
\text { ACCOUNT }(1+2)\end{array}$ & 3.2 & 9.2 & -3.3 & -35.8 & -90.4 & -116.3 & -138.4 & -150.8 & -109.6 & -99.2 & -85.5 \\
\hline 4.CAPITAL ACC. & -20.7 & -26.0 & -25.0 & 23.0 & 80.8 & 105.2 & 118.0 & 160.2 & 143.9 & 74.8 & 62.4 \\
\hline Foreign invest. & 8.3 & 31.0 & 23.0 & 4.5 & 37.4 & 74.5 & 92.9 & 85.1 & 101.1 & 98.44 & 4.53 \\
\hline Short term cap. & -29.0 & -57.0 & -48.0 & 18.5 & 43.4 & 30.7 & 25.0 & 75.1 & 42.8 & -23.61 & 57.91 \\
\hline $\begin{array}{l}\text { 5. FUNDAMENTAL } \\
\text { BOP }(3+4)\end{array}$ & -17.6 & -16.7 & -28.3 & -12.8 & -9.6 & -11.1 & -20.4 & 9.4 & 34.3 & -24.3 & -23.1 \\
\hline $\begin{array}{l}\text { 6. NET FOREIGN } \\
\text { POSITION }\end{array}$ & 365.5 & 356.1 & 235.9 & 257.4 & 134.1 & 96.9 & 100.8 & 50.5 & 10.5 & -47.0 & -164.5 \\
\hline Assets & 755.4 & 820.1 & 961.0 & 1129.7 & 1127.1 & 1302.7 & 1594.7 & 1758.7 & 2008.4 & 2350.2 & 2294.1 \\
\hline Liabilities & 389.9 & 464.0 & 725.1 & 872.3 & 993.0 & 1205.8 & 1493.9 & 1708.2 & 1997.9 & 2397.2 & 2458.6 \\
\hline
\end{tabular}


Table A4. United States' international payments and net foreign position, 1991-2002 (billions of dollars)

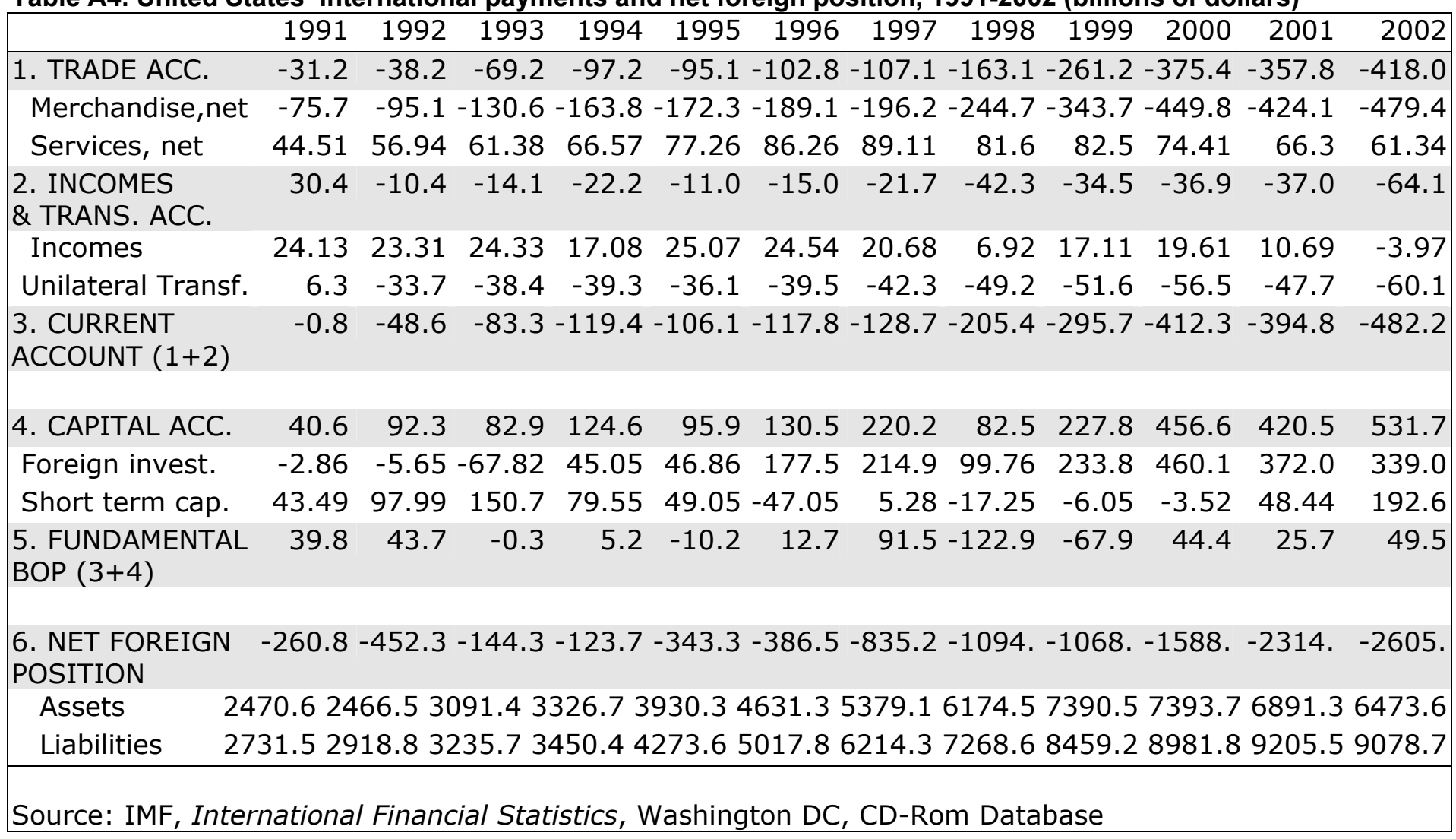


1989. 1. Knowledge and Prediction of Economic Behaviour: Towards A Constructivist Approach. by Roberto Tamborini.

1989. 2. Export Stabilization and Optimal Currency Baskets: the Case of Latin American Countries. by Renzo G.Avesani Giampiero M. Gallo and Peter Pauly.

1989. 3. Quali garanzie per $i$ sottoscrittori di titoli di Stato? Una rilettura del rapporto della Commissione Economica dell'Assemblea Costituente di Franco Spinelli e Danilo Vismara.

(What Guarantees to the Treasury Bill Holders? The Report of the Assemblea Costituente Economic Commission Reconsidered by Franco Spinelli and Danilo Vismara.)

1989. 4. L'intervento pubblico nell'economia della "Venezia Tridentina" durante l'immediato dopoguerra di Angelo Moioli.

(The Public Intervention in "Venezia Tridentina" Economy in the First War Aftermath by Angelo Moioli.)

1989. 5. L'economia lombarda verso la maturità dell'equilibrio agricolo-commerciale durante l'età delle riforme di Angelo Moioli.

(The Lombard Economy Towards the Agriculture-Trade Equilibrium in the Reform Age by Angelo Moioli.)

1989. 6. L'identificazione delle allocazioni dei fattori produttivi con il duale. di Quirino Paris e di Luciano Pilati.

(Identification of Factor Allocations Through the Dual Approach by Quirino Paris and Luciano Pilati.)

1990. 1. Le scelte organizzative e localizzative dell'amministrazione postale: un modello intrpretativo.di Gianfranco Cerea.

(The Post Service's Organizational and Locational Choices: An Interpretative Model by Gianfranco Cerea.)

1990. 2. Towards a Consistent Characterization of the Financial Economy. by Roberto Tamborini. 
1990. 3. Nuova macroeconomia classica ed equilibrio economico generale: considerazioni sulla pretesa matrice walrasiana della N.M.C. di Giuseppe Chirichiello.

(New Classical Macroeconomics and General Equilibrium: Some Notes on the Alleged Walrasian Matrix of the N.C.M.by Giuseppe Chirichiello.)

1990. 4. Exchange Rate Changes and Price Determination in Polypolistic Markets. by Roberto Tamborini.

1990. 5. Congestione urbana e politiche del traffico. Un'analisi economica di Giuseppe Folloni e Gianluigi Gorla.

(Urban Congestion and Traffic Policy. An Economic Analysis by Giuseppe Folloni and Gianluigi Gorla.)

1990. 6. Il ruolo della qualità nella domanda di servizi pubblici. Un metodo di analisi empirica di Luigi Mittone.

(The Role of Quality in the Demand for Public Services. A Methodology for Empirical Analysis by Luigi Mittone.)

1991. 1. Consumer Behaviour under Conditions of Incomplete Information on Quality: a Note by Pilati Luciano and Giuseppe Ricci.

1991. 2. Current Account and Budget Deficit in an Interdependent World by Luigi Bosco.

1991. 3. Scelte di consumo, qualità incerta e razionalità limitata di Luigi Mittone e Roberto Tamborini.

(Consumer Choice, Unknown Quality and Bounded Rationality by Luigi Mittone and Roberto Tamborini.)

1991. 4. Jumping in the Band: Undeclared Intervention Thresholds in a Target Zone by Renzo G. Avesani and Giampiero M. Gallo.

1991. 5 The World Tranfer Problem. Capital Flows and the Adjustment of Payments by Roberto Tamborini.

1992.1 Can People Learn Rational Expectations? An Ecological Approach by Pier Luigi Sacco. 
1992.2 On Cash Dividends as a Social Institution by Luca Beltrametti.

1992.3 Politica tariffaria e politica informativa nell'offerta di servizi pubblici di Luigi Mittone

(Pricing and Information Policy in the Supply of Public Services by Luigi Mittone.)

1992.4 Technological Change, Technological Systems, Factors of Production by Gilberto Antonelli and Giovanni Pegoretti.

1992.5 Note in tema di progresso tecnico di Geremia Gios e Claudio Miglierina.

(Notes on Technical Progress, by Geremia Gios and Claudio Miglierina).

1992.6 Deflation in Input Output Tables by Giuseppe Folloni and Claudio Miglierina.

1992.7 Riduzione della complessità decisionale: politiche normative e produzione di informazione di Luigi Mittone

(Reduction in decision complexity: normative policies and information production by Luigi Mittone)

1992.8 Single Market Emu and Widening. Responses to Three Institutional Shocks in the European Community by Pier Carlo Padoan and Marcello Pericoli

1993.1 La tutela dei soggetti "privi di mezzi": Criteri e procedure per la valutazione della condizione economica di Gianfranco Cerea

(Public policies for the poor: criteria and procedures for a novel means test by Gianfranco Cerea )

1993.2 La tutela dei soggetti "privi di mezzi": un modello matematico per la rappresentazione della condizione economica di Wolfgang J. Irler

(Public policies for the poor: a mathematical model for a novel means test by Wolfgang J.Irler)

1993.3 Quasi-markets and Uncertainty: the Case of General Proctice Service by Luigi Mittone 
1993.4 Aggregation of Individual Demand Functions and Convergence to Walrasian Equilibria by Dario Paternoster

1993.5 A Learning Experiment with Classifier System: the Determinants of the Dollar-Mark Exchange Rate by Luca Beltrametti, Luigi Marengo and Roberto Tamborini

1993.6 Alcune considerazioni sui paesi a sviluppo recente di Silvio Goglio

(Latecomer Countries: Evidence and Comments by Silvio Goglio)

1993.7 Italia ed Europa: note sulla crisi dello SME di Luigi Bosco

(Italy and Europe: Notes on the Crisis of the EMS by Luigi Bosco)

1993.8 Un contributo all'analisi del mutamento strutturale nei modelli input-output di Gabriella Berloffa

(Measuring Structural Change in Input-Output Models: a Contribution by Gabriella Berloffa)

1993.9 On Competing Theories of Economic Growth: a Cross-country Evidence by Maurizio Pugno

1993.10 Le obbligazioni comunali di Carlo Buratti (Municipal Bonds by Carlo Buratti)

1993.11 Due saggi sull'organizzazione e il finanziamento della scuola statale di Carlo Buratti

(Two Essays on the Organization and Financing of Italian State Schools by Carlo Buratti

1994.1 Un'interpretazione della crescita regionale: leaders, attività indotte e conseguenze di policy di Giuseppe Folloni e Silvio Giove. (A Hypothesis about regional Growth: Leaders, induced Activities and Policy by Giuseppe Folloni and Silvio Giove).

1994.2 Tax evasion and moral constraints: some experimental evidence by Luigi Bosco and Luigi Mittone. 
1995.1 A Kaldorian Model of Economic Growth with Shortage of Labour and Innovations by Maurizio Pugno.

1995.2 A che punto è la storia d'impresa? Una riflessione storiografica e due ricerche sul campo a cura di Luigi Trezzi.

1995.3 Il futuro dell'impresa cooperativa: tra sistemi, reti ed ibridazioni di Luciano Pilati.

(The future of the cooperative enterprise: among systems, networks and hybridisation by Luciano Pilati).

1995.4 Sulla possibile indeterminatezza di un sistema pensionistico in perfetto equilibrio finanziario di Luca Beltrametti e Luigi Bonatti.

(On the indeterminacy of a perfectly balanced social security system by Luca Beltrametti and Luigi Bonatti).

1995.5 Two Goodwinian Models of Economic Growth for East Asian NICs by Maurizio Pugno.

1995.6 Increasing Returns and Externalities: Introducing Spatial Diffusion into Krugman's Economic Geography by Giuseppe Folloni and Gianluigi Gorla.

1995.7 Benefit of Economic Policy Cooperation in a Model with Current Account Dynamics and Budget Deficit by Luigi Bosco.

1995.8 Coalition and Cooperation in Interdependent Economies by Luigi Bosco.

1995.9 La finanza pubblica italiana e l'ingresso nell'unione monetaria europea di Ferdinando Targetti.

(Italian Public Finance and the Entry in the EMU by Ferdinando Targetti)

1996.1 Employment, Growth and Income Inequality: some open Questions by Annamaria Simonazzi and Paola Villa.

1996.2 Keynes' Idea of Uncertainty: a Proposal for its Quantification by Guido Fioretti. 
1996.3 The Persistence of a "Low-Skill, Bad-Job Trap" in a Dynamic Model of a Dual Labor Market by Luigi Bonatti.

1996.4 Lebanon: from Development to Civil War by Silvio Goglio.

1996.5 A Mediterranean Perspective on the Break-Down of the Relationship between Participation and Fertility by Francesca Bettio and Paola Villa.

1996.6 Is there any persistence in innovative activities? by Elena Cefis.

1997.1 Imprenditorialità nelle alpi fra età moderna e contemporanea a cura di Luigi Trezzi.

1997.2 Il costo del denaro è uno strumento anti-inflazionistico? di Roberto Tamborini.

(Is the Interest Rate an Anti-Inflationary Tool? by Roberto Tamborini).

1997.3 A Stability Pact for the EMU? by Roberto Tamborini.

1997.4 Mr Keynes and the Moderns by Axel Leijonhufvud.

1997.5 The Wicksellian Heritage by Axel Leijonhufvud.

1997.6 On pension policies in open economies by Luca Beltrametti and Luigi Bonatti.

1997.7 The Multi-Stakeholders Versus the Nonprofit Organisation by Carlo Borzaga and Luigi Mittone.

1997.8 How can the Choice of a Tme-Consistent Monetary Policy have Systematic Real Effects? by Luigi Bonatti.

1997.9 Negative Externalities as the Cause of Growth in a Neoclassical Model by Stefano Bartolini and Luigi Bonatti. 
1997.10 Externalities and Growth in an Evolutionary Game by Angelo Antoci and Stefano Bartolini.

1997.11 An Investigation into the New Keynesian Macroeconomics of Imperfect Capital Markets by Roberto Tamborini.

1998.1 Assessing Accuracy in Transition Probability Matrices by Elena Cefis and Giuseppe Espa.

1998.2 Microfoundations: Adaptative or Optimizing? by Axel Leijonhufvud.

1998.3 Clower's intellectual voyage: the 'Ariadne's thread' of continuity through changes by Elisabetta De Antoni.

1998.4 The Persistence of Innovative Activities. A Cross-Countries and Cross-Sectors Comparative Analysis by Elena Cefis and Luigi Orsenigo

1998.5 Growth as a Coordination Failure by Stefano Bartolini and Luigi Bonatti

1998.6 Monetary Theory and Central Banking by Axel Leijonhufvud

1998.7 Monetary policy, credit and aggregate supply: the evidence from Italy by Riccardo Fiorentini and Roberto Tamborini

1998.8 Stability and multiple equilibria in a model of talent, rent seeking, and growth by Maurizio Pugno

1998.9 Two types of crisis by Axel Leijonhufvud

1998.10 Trade and labour markets: vertical and regional differentiation in Italy by Giuseppe Celi e Maria Luigia Segnana

1998.11 Utilizzo della rete neurale nella costruzione di un trading system by Giulio Pettenuzzo

1998.12 The impact of social security tax on the size of the informal economy by Luigi Bonatti 
1999.1 L'economia della montagna interna italiana: un approccio storiografico, a cura di Andrea Leonardi e Andrea Bonoldi.

1999.2 Unemployment risk, labour force participation and savings, by Gabriella Berloffa e Peter Simmons

1999.3 Economia sommersa, disoccupazione e crescita, by Maurizio Pugno

1999.4 The nationalisation of the British Railways in Uruguay, by Giorgio Fodor

1999.5 Elements for the history of the standard commodity, by Giorgio Fodor

1999.6 Financial Market Imperfections, Heterogeneity and growth, by Edoardo Gaffeo

1999.7 Growth, real interest, employment and wage determination, by Luigi Bonatti

2000.1 A two-sector model of the effects of wage compression on unemployment and industry distribution of employment, by Luigi Bonatti

2000.2 From Kuwait to Kosovo: What have we learned? Reflections on globalization and peace, by Roberto Tamborini

2000.3 Metodo e valutazione in economia. Dall'apriorismo a Friedman, by Matteo Motterlini

2000.4 Under tertiarisation and unemployment. by Maurizio Pugno

2001.1 Growth and Monetary Rules in a Model with Competitive Labor Markets, by Luigi Bonatti.

2001.2 Profit Versus Non-Profit Firms in the Service Sector: an Analysis of the Employment and Welfare Implications, by Luigi Bonatti, Carlo Borzaga and Luigi Mittone. 
2001.3 Statistical Economic Approach to Mixed Stock-Flows Dynamic Models in Macroeconomics, by Bernardo Maggi and Giuseppe Espa.

2001.4 The monetary transmission mechanism in Italy: The credit channel and a missing ring, by Riccardo Fiorentini and Roberto Tamborini.

2001.5 Vat evasion: an experimental approach, by Luigi Mittone

2001.6 Decomposability and Modularity of Economic Interactions, by Luigi Marengo, Corrado Pasquali and Marco Valente.

2001.7 Unbalanced Growth and Women's Homework, by Maurizio Pugno

2002.1 The Underground Economy and the Underdevelopment Trap, by Maria Rosaria Carillo and Maurizio Pugno.

2002.2 Interregional Income Redistribution and Convergence in a Model with Perfect Capital Mobility and Unionized Labor Markets, by Luigi Bonatti.

2002.3 Firms' bankruptcy and turnover in a macroeconomy, by Marco Bee, Giuseppe Espa and Roberto Tamborini.

2002.4 One "monetary giant" with many "fiscal dwarfs": the efficiency of macroeconomic stabilization policies in the European Monetary Union, by Roberto Tamborini.

2002.5 The Boom that never was? Latin American Loans in London 1822-1825, by Giorgio Fodor.

2002.6 L'economia senza banditore di Axel Leijonhufoud: le 'forze oscure del tempo e dell'ignoranza' e la complessità del coordinamento, by Elisabetta De Antoni.

2002.7 Why is Trade between the European Union and the Transition Economies Vertical?, by Hubert Gabrisch and Maria Luigia Segnana. 
2003.1 The service paradox and endogenous economic gorwth, by Maurizio Pugno.

2003.2 Mappe di probabilità di sito archeologico: un passo avanti, di Giuseppe Espa, Roberto Benedetti, Anna De Meo e Salvatore Espa.

(Probability maps of archaeological site location: one step beyond, by Giuseppe Espa, Roberto Benedetti, Anna De Meo and Salvatore Espa).

2003.3 The Long Swings in Economic Understianding, by Axel Leijonhufvud.

2003.4 Dinamica strutturale e occupazione nei servizi, di Giulia Felice.

2003.5 The Desirable Organizational Structure for Evolutionary Firms in Static Landscapes, by Nicolás Garrido.

2003.6 The Financial Markets and Wealth Effects on Consumption An Experimental Analysis, by Matteo Ploner.

2003.7 Essays on Computable Economics, Methodology and the Philosophy of Science, by Kumaraswamy Velupillai.

2003.8 Economics and the Complexity Vision: Chimerical Partners or Elysian Adventurers?, by Kumaraswamy Velupillai.

2003.9 Contratto d'area cooperativo contro il rischio sistemico di produzione in agricoltura, di Luciano Pilati e Vasco Boatto.

2003.10 Il contratto della docenza universitaria. Un problema multitasking, di Roberto Tamborini.

2004.1 Razionalità e motivazioni affettive: nuove idee dalla neurobiologia e psichiatria per la teoria economica? di Maurizio Pugno.

(Rationality and affective motivations: new ideas from neurobiology and psychiatry for economic theory? by Maurizio Pugno. 
2004.2 The economic consequences of Mr. G. W. Bush's foreign policy. Can th US afford it? by Roberto Tamborini 
PUBBLICAZIONE REGISTRATA PRESSO IL TRIBUNALE DI TRENTO 